\title{
Combined Waste Form Cost Trade Study
}

\author{
Dirk Gombert \\ Steve Piet \\ Timothy Trickel \\ Joe Carter \\ John Vienna \\ Bill Ebert
}

November 2008

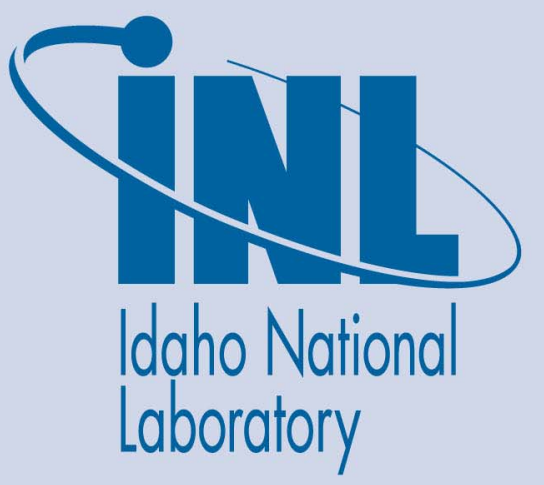

The INL is a U.S. Department of Energy National Laboratory operated by Battelle Energy Alliance 
INL/EXT-08-14993

GNEP-SYSA-PMO-MI-DV-2009-000003

\title{
Combined Waste Form Cost Trade Study
}

${ }^{4}$ ANL

\author{
Dirk Gombert \\ Steve Piet \\ Timothy Trickel ${ }^{1}$ \\ Joe Carter ${ }^{2}$ \\ John Vienna ${ }^{3}$ \\ Bill Ebert ${ }^{4}$
}

November 2008

\section{Idaho National Laboratory Idaho Falls, Idaho 83415}

http://www.inl.gov

Prepared for the U.S. Department of Energy Office of Nuclear Energy Under DOE Idaho Operations Office

Contract DE-AC07-05ID14517 


\section{DISCLAIMER}

This information was prepared as an account of work sponsored by an agency of the U.S. Government. Neither the U.S. Government nor any agency thereof, nor any of their employees, makes any warranty, expressed or implied, or assumes any legal liability or responsibility for the accuracy, completeness, or usefulness, of any information, apparatus, product, or process disclosed, or represents that its use would not infringe privately owned rights. References herein to any specific commercial product, process, or service by trade name, trade mark, manufacturer, or otherwise, does not necessarily constitute or imply its endorsement, recommendation, or favoring by the U.S. Government or any agency thereof. The views and opinions of authors expressed herein do not necessarily state or reflect those of the U.S. Government or any agency thereof. 
Reviewed by:

Consulting Engineer, Author

Director, Systems Analysis Campaign

Representative, Technical Integration Office
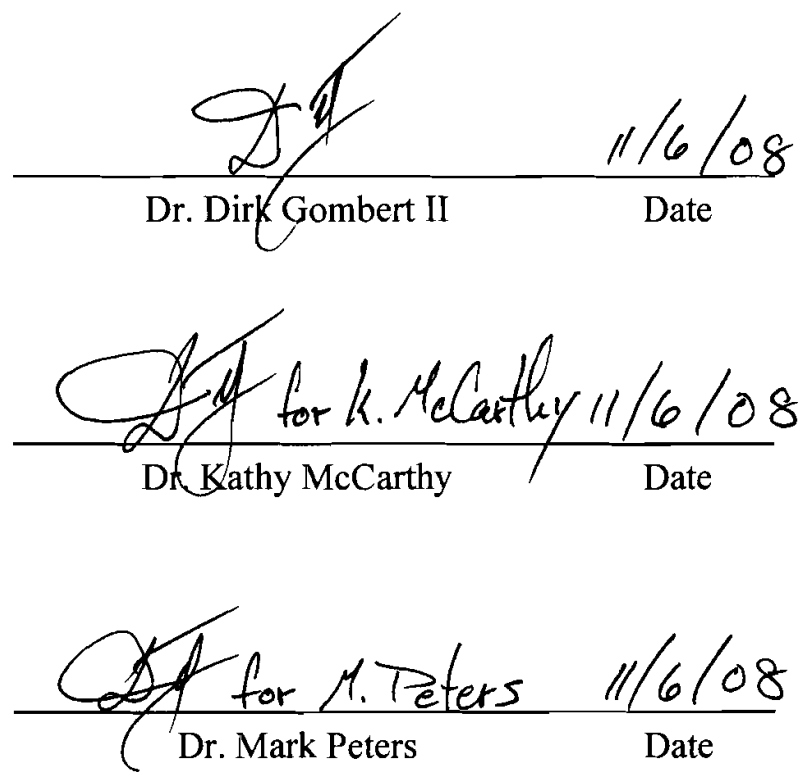


\section{EXECUTIVE SUMMARY}

A new generation of aqueous nuclear fuel reprocessing, now in development under the auspices of the DOE Office of Nuclear Energy (NE), separates fuel into several fractions, thereby partitioning the wastes into groups of common chemistry. This technology advance enables development of waste management strategies that were not conceivable with PUREX reprocessing. Conventional wisdom suggests minimizing high level waste (HLW) volume is desirable, but logical extrapolation of this concept suggests that at some point the cost of reducing volume further will reach a point of diminishing return and may cease to be cost-effective. This report summarizes an evaluation considering groupings of wastes in terms of cost-benefit for the reprocessing system that concludes it is very difficult to justify the costs of HLW treatment facilities for additional specialized waste forms by reducing HLW disposal costs.

Internationally, the typical waste form for HLW from the PUREX process is borosilicate glass containing waste elements as oxides. Unfortunately several fission products (primarily the noble metals $\mathrm{Ru}, \mathrm{Rh}, \mathrm{Pd}$ ) have limited solubility in glass, yielding relatively low waste loading, producing more glass, and greater disposal costs. Advanced separations allow matching the waste form to waste stream chemistry, enabling the disposal system to achieve more optimum waste loading with improved performance. Metals can be segregated from oxides and each can be stabilized in forms to minimize the HLW volume for repository disposal. Thus, a more efficient waste management system making the most effective use of advanced waste forms and disposal design for each waste is enabled by advanced separations and how the waste streams are combined. This trade-study was designed to juxtapose a combined waste form baseline waste treatment scheme with two options and to evaluate the cost-benefit using available data from the conceptual design studies supported by DOE-NE. The three strategies included:

1. Base case: $\mathrm{Cs} / \mathrm{Sr}$ glass, Ln/TMFP glass, and UDS/Tc alloy

2. Glass case: $\mathrm{Cs} / \mathrm{Sr} / \mathrm{Ln} / \mathrm{TMFP}$ glass and UDS/Tc alloy

3. Alloy case: $\mathrm{Cs} / \mathrm{Sr} / \mathrm{Ln}$ glass and UDS/Tc/TMFP alloy

The alloy case, combining all of the metals including undissolved solids (UDS), technetium (Tc), and transition metal fission products (TMFP) in a metallic alloy and the oxides of the alkali/alkaline earth elements primarily cesium, strontium $(\mathrm{Cs} / \mathrm{Sr})$, and lanthanides $(\mathrm{Ln})$ in glass minimizes HLW volume. Implementing a waste management strategy using these state-of-the-art combined waste forms and storage to allow radioactive decay and heat dissipation prior to placement in a repository, makes it possible to place up to 10x the HLW equivalent of SNF in the same repository space.

All waste management strategies considered with reprocessing significantly reduced HLW costs versus direct disposal of spent nuclear fuel (SNF). However, using generic costs based on preliminary studies for typical waste stabilization facilities and separations modules, this analysis shows that a fourth strategy, resulting in only one waste form with all wastes in glass is the most cost-effective. Sensitivity studies considering weight and heat limits, separations additives, waste loading and HLW disposal costs indicate that this conclusion is robust over a wide range of these variables. This is because relative HLW disposal savings amongst the four strategies evaluated are measured in multiples of $\$ 10 \mathrm{M}$, whereas the capital costs are in multiples of \$1B. Thus it is very difficult to justify the costs of HLW treatment facilities for dedicated waste forms by reducing HLW disposal costs based on canister count.

One final observation is that while advanced waste forms can accomplish the goal of putting up to a factor of 10x more SNF equivalent as HLW in the current repository design, additional measures will likely be necessary to increase this multiplier further. Far more important than reducing volume is 1) recycling the actinides for energy recovery and transmutation, and 2) decay storage to manage heat from the HLW glass prior to final disposition. This strategy makes the repository temperature constraints non-limiting, and then canister disposal costs are primarily a function of transportation, handling, and drift length in the 
repository. An added benefit is reduction of long-term radiotoxicity of the waste by removing the actinides.

These results could be leveraged for use in a follow-on study for an overall HLW management strategy considering heat. 


\section{CONTENTS}

EXECUTIVE SUMMARY $\mathrm{V}$

ACRONYMS ix

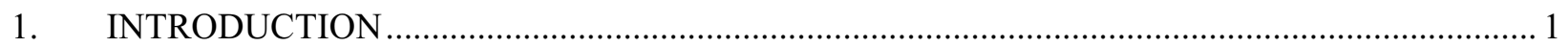

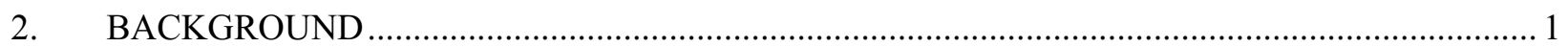

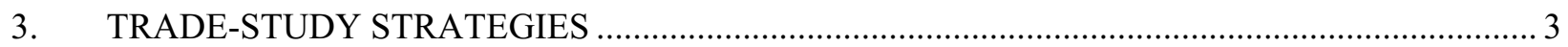

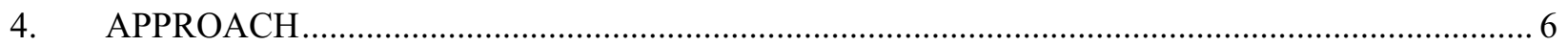

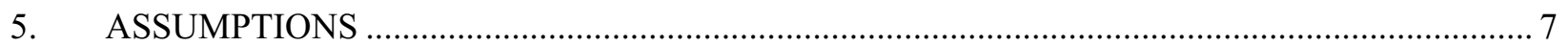

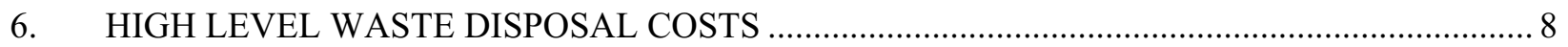

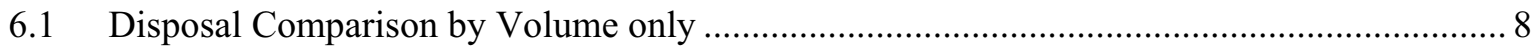

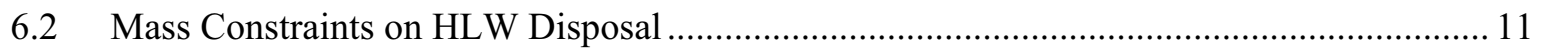

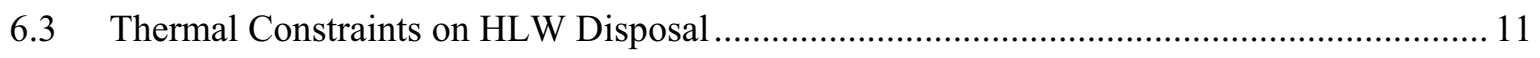

6.4 Estimating Potential Savings in HLW Costs .................................................................... 13

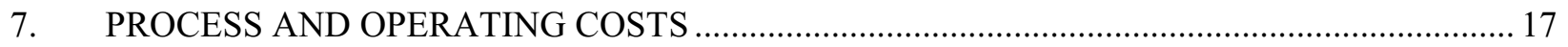

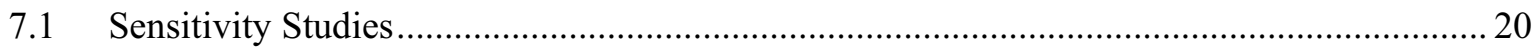

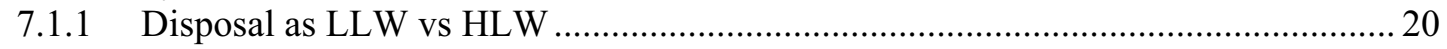

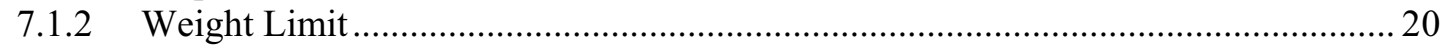

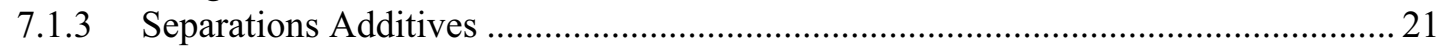

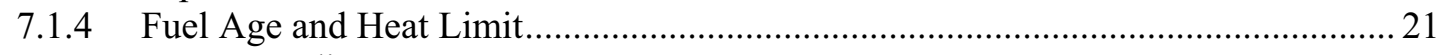

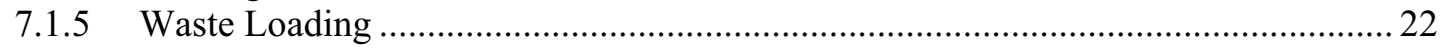

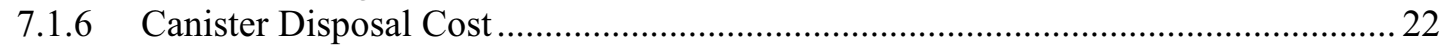

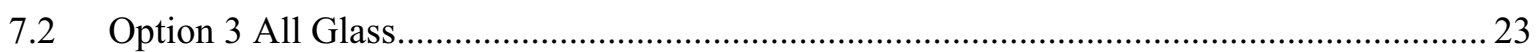

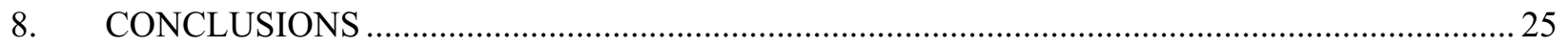

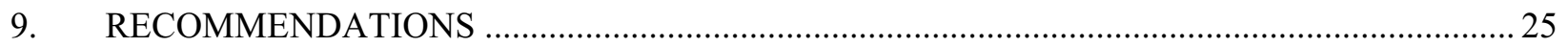

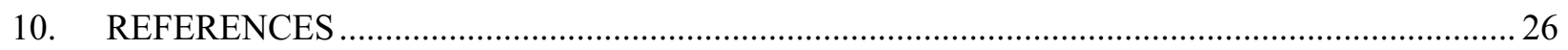

\section{FIGURES}

Figure 1. Example reprocessing scheme to recover transuranic elements............................................. 1

Figure 2. Combined waste form baseline waste treatment concept supporting advanced aqueous

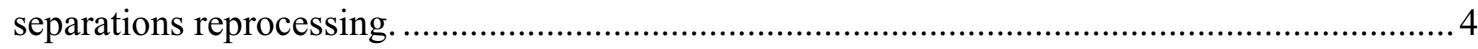

Figure 3. Glass option waste treatment concept with $\mathrm{Cs} / \mathrm{Sr} / \mathrm{Ln} / \mathrm{TMFP}$ in the oxide waste form.................5

Figure 4. Alloy option waste treatment concept with $\mathrm{Cs} / \mathrm{Sr} / \mathrm{Ln} / \mathrm{TMFP}$ in the oxide waste form and

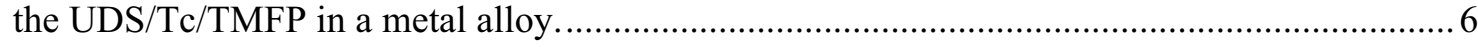

Figure 5. Summary of cost module addition and reductions to make relative comparison. ....................... 7 
Figure 6. Schematic Illustration of the Emplacement Drift with Cutaway Views of Different Waste Packages. 9

Figure 7. Conceptual heat transfer model for waste canister in storage vault. 12

Figure 8. Comparison of waste management options by volume of waste. 14

Figure 9. Comparison of waste management options by number of waste canisters. .15

Figure 10. Comparison of waste strategy costs over time normalized to baseline 19

Figure 11. Comparison of waste strategy costs over time normalized to baseline with $\mathrm{Cs} / \mathrm{Sr}$ and Ln waste disposed as LLW.

Figure 12. Comparison of waste strategy costs over time normalized to baseline with fuel aged $\sim 112$ years total or eliminating the heat limit.

Figure 13. Comparison of waste strategy costs over time normalized to baseline with glass waste loading reduced $50 \%$.

Figure 14. Long-term cost profile of one glass waste form versus other waste management strategies.

\section{TABLES}

Table 1. Waste streams and GNEP baseline disposition for aqueous (UREX) reprocessing. ..................... 2

Table 2. Waste Stream Mass, and Stabilized Waste Form Data........................................................... 8

Table 3. Summary of comparison of disposal volume relative to direct disposal of SNF....................... 11

Table 4. Summary of waste form densities and allowable fill efficiencies for standard $0.61 \mathrm{~m}$

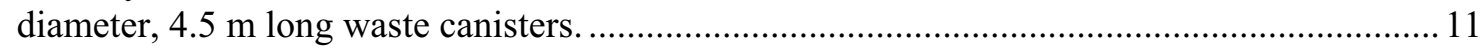

Table 5. Glass ${ }^{*}$ canister maximum diameter to maintain centerline temperature $\mathrm{T}_{\mathrm{C}}<\left(\mathrm{T}_{\mathrm{G}} \mathrm{x} 0.9\right)^{* *} \ldots \ldots \ldots \ldots . . \ldots 13$

Table 6. Waste strategy SNF/HLW disposal comparison for 800 MTHM/yr ....................................... 16

Table 7. Capital and operating cost comparison for waste management strategies for $800 \mathrm{MTHM} / \mathrm{yr}$ 


\section{ACRONYMS}

ANL Argonne National Laboratory

BNFP Barnwell Nuclear Fuel Plant

BSG borosilicate glass

BWR boiling water reactor

CCD/PEG chlorinated cobalt dicarbollide-polyethylene glycol

CFR code of federal regulations

$\mathrm{CO}_{2} \quad$ carbon dioxide

CWF ceramic waste form

D\&D decommissioning and demolition

DOE United States Department of Energy

DU depleted uranium

Echem Electrochemical processing also called pyrochemical processing

EIS Environmental Impact Statement

EM Office of Environmental Management (a Program Office in the United States Department of Energy)

ENS Enhanced Near Surface

EPA United States Environmental Protection Agency

ERL economic recovery limit

FP fission products

FPEX fission product extraction

GNEP Global Nuclear Energy Partnership

GTCC greater than Class C

GWd gigawatt-days

HEU highly enriched uranium

HLW high-level waste

HTO Tritiated water (hydrogen-tritium oxide, or water containing tritium)

INL Idaho National Laboratory

IWMS Integrated Waste Management Strategy

LLW low-level waste (also LLW-SLB or LLW in Class A, B, or C that is acceptable for SLB)

LWR light water reactor

MOX mixed U-Pu oxide (fuel)

MTHM metric tons of heavy metal

MTIHM metric tons of initial heavy metal (actinide metals prior to irradiation) 
MWF metal waste form

$\mathrm{nCi}$

nano-curie, one billionth of a curie

$\mathrm{NE}$

Office of Nuclear Energy (a Program Office in the United States Department of Energy)

NRC

United States Nuclear Regulatory Commission

PPE

personal protective equipment

PWR pressurized water reactor

$\mathrm{R} \& \mathrm{D} \quad$ research and development

RCRA Resource Conservation and Recovery Act

RW Office of Civilian Radioactive Waste Management (Program Office in the United States Department of Energy)

SLB shallow land burial

SNF spent nuclear fuel

SNL Sandia National Laboratory

SRNL Savannah River National Laboratory

SS stainless steel

TALSPEAK Trivalent Actinide Lanthanide Separations by Phosphorus-reagent Extraction from Aqueous Komplexes

TRU transuranic

TRUEX transuranic extraction

UDS undissolved solids

UREX Uranium extraction (an aqueous separations process or in the case of variations UREX+, UREX+1a, etc., a family of aqueous separations processes)

WIPP Waste Isolation Pilot Plant

YMF Yucca Mountain Facility 


\section{COMBINED WASTE FORM COST TRADE STUDY}

\section{INTRODUCTION}

A new generation of aqueous nuclear fuel reprocessing, now in development under the auspices of the DOE (DOE) Office of Nuclear Energy (NE), separates fuel into several fractions, thereby partitioning the wastes into groups of common chemistry. Advanced separations make possible recycling of long-lived hazardous elements as nuclear fuel so they can be transmuted into shorter-lived wastes. In doing so, wastes are partitioned in a manner that enables development of specialized waste forms to more effectively immobilize groups of radionuclides to reduce volume, efficiently manage decay heat, and enhance overall disposal system performance. Conventional wisdom suggests minimizing high level waste (HLW) volume is desirable, but logical extrapolation of this concept suggests that at some point the cost of reducing volume further may cease to be cost-effective. This report summarizes an evaluation considering three groupings of wastes in terms of cost-benefit for the reprocessing system.

\section{BACKGROUND}

The fuel-reprocessing concept considered here includes the streams derived from advanced aqueous separations such as UREX $+1 \mathrm{a}$, or a similar scheme. ${ }^{1,2}$ Intrinsic to this evaluation is the policy choice to recover transuranic (TRU) elements including plutonium $(\mathrm{Pu})$ and the minor actinides (americium, neptunium, and curium or collectively MA) from spent nuclear fuel (SNF) for both energy recovery and to transmute them into shorter-lived wastes. Aqueous reprocessing concepts to recover MA share preliminary process steps to dissolve fuel, separate uranium, and partition most of the fission products prior to the ultimate segregation of rare earth lanthanide (Ln) elements from the MA. In addition, another separation can be added to partition the alkali and alkaline-earth elements including cesium and strontium (Cs/Sr) for decay storage to dissipate relatively short term ( $\sim 100$ years) heat prior to disposal in a geologic repository. The UREX +1 a scheme developed under DOE funding is shown as example in Figure 1. Similar schemes are in development by the United Kingdom, France, and others.

SNF Reprocessing

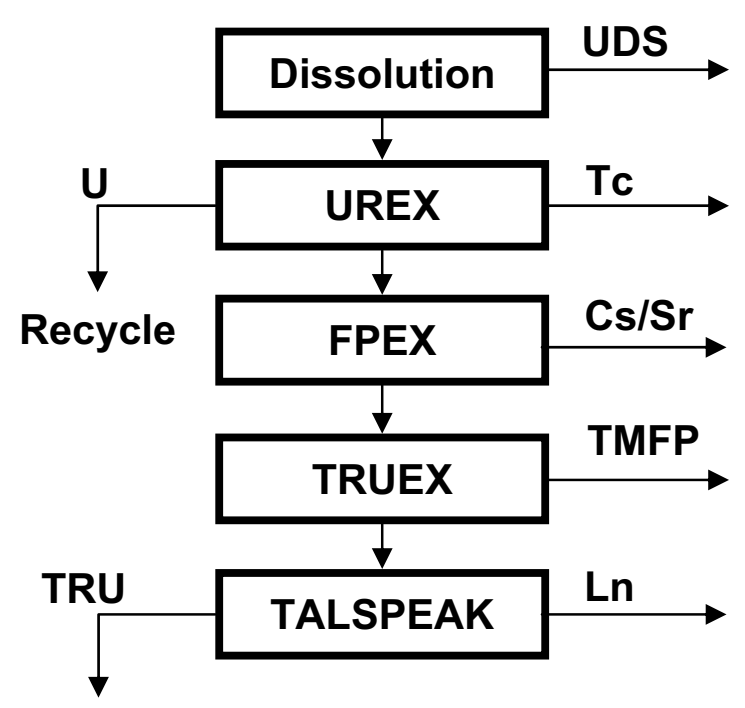

Figure 1. Example reprocessing scheme to recover transuranic elements. 
A credible strategy for managing radioactive wastes from any future nuclear fuel-cycle must provide acceptable disposition paths for all wastes regardless of reactor technology, fuel reprocessing scheme(s), and/or the degree of fuel-cycle closure. In development of a proposed waste management strategy to support a future scenario using advanced separations in fuel reprocessing, a set of baseline waste forms was developed. ${ }^{3}$ An effective strategy should provide guidance to optimize waste management aspects of the fuel-cycle to provide a safe, secure, and cost-effective practicable system considering waste/storage form(s) and how they impact performance of the system as a whole. Considering feedback from ongoing research, the integrated waste management strategy (IWMS) updated the listing of the waste form baseline for primary aqueous reprocessing wastes as shown in Table $1{ }^{4}$ The IWMS and Baseline Study references also include more complete description of the waste streams, their derivation, and technical aspects of the baseline selection.

Table 1. Waste streams and GNEP baseline disposition for aqueous (UREX) reprocessing.

\begin{tabular}{|l|l|l|}
\hline \multicolumn{1}{|c|}{$\begin{array}{c}\text { Aqueous } \\
\text { Process Stream }\end{array}$} & \multicolumn{1}{|c|}{ Stream Description/Derivation } & \multicolumn{1}{c|}{ Baseline Waste Form Disposition } \\
\hline $\begin{array}{l}\text { Undissolved } \\
\text { Solids (UDS) }\end{array}$ & $\begin{array}{l}\text { Sludge from dissolver bottom and } \\
\text { clarifier solids containing noble } \\
\text { metals and some transuranics (TRU) }\end{array}$ & $\begin{array}{l}\text { Metal alloy with Tc possibly containing } \\
\text { transition metal FP. Matrix may also } \\
\text { contain cladding/hardware. }\end{array}$ \\
\hline $\begin{array}{l}\text { Technetium } \\
\text { (Tc) }\end{array}$ & $\begin{array}{l}\text { Acid side ion-exchange of UREX } \\
\text { raffinate to be stripped or pyrolyzed } \\
\text { and reduced to Tc metal }\end{array}$ & $\begin{array}{l}\text { Metal alloy possibly containing UDS and } \\
\text { transition metal FP. }\end{array}$ \\
\hline $\begin{array}{l}\text { Alkali/Alkaline } \\
\text { Earth (Cs/Sr) }\end{array}$ & $\begin{array}{l}\text { FPEX solvent extraction of UREX } \\
\text { raffinate, yields Cs, Sr, barium (Ba), } \\
\text { and rubidium (Rb) }\end{array}$ & $\begin{array}{l}\text { Glass or ceramic may include lanthanide } \\
\text { stream. }\end{array}$ \\
\hline $\begin{array}{l}\text { Transition } \\
\text { Metal Fission } \\
\text { Products } \\
\text { (TMFP) }\end{array}$ & $\begin{array}{l}\text { TRUEX raffinate from separation of } \\
\text { rare earth (lanthanides Ln) and TRU } \\
\text { (MA) from balance of fission } \\
\text { products: Fe, Ru, Pd, Rh, Zr, Mo }\end{array}$ & $\begin{array}{l}\text { Metal alloy potentially combined with Tc } \\
\text { and UDS. } \\
\text { Borosilicate glass if combined with } \\
\text { lanthanides (potentially with Cs/Sr). }\end{array}$ \\
\hline $\begin{array}{l}\text { Lanthanides } \\
\text { (Ln) }\end{array}$ & $\begin{array}{l}\text { TALSPEAK } \text { d product separated from } \\
\text { minor actinides (MA). This waste } \\
\text { includes: Y, Ln, Ce, Nd, and other } \\
\text { lanthanides. }\end{array}$ & $\begin{array}{l}\text { Glass- borosilicate glass if segregated as } \\
\text { separate Ln stream. May be combined with } \\
\text { Cs/Sr and/or transition metal fission } \\
\text { products. }\end{array}$ \\
\hline $\begin{array}{l}\text { a. CCD/PEG - chlorinated cobalt dicarbollide-polyethylene glycol } \\
\text { b. FPEX - fission product extraction } \\
\text { c. TRUEX - transuranic extraction } \\
\text { d. TALSPEAK - Trivalent Actinide Lanthanide Separations by Phosphorus-reagent Extraction from Aqueous Complexes }\end{array}$ \\
\hline
\end{tabular}

The FPEX separation shown in Figure 1 is optional to recovering TRU, but it plays a pivotal role in a waste management strategy. This process isolates readily oxidized alkali/alkaline earth elements from the rest of the elements in the fuel. Doing this prior to TRUEX, allows the TRUEX process to isolate the dissolved transition metals, the balance of which are left in the undissolved solids. For the purposes of this report the alkali/alkaline earth waste stream is henceforth referred to simply as $\mathrm{Cs} / \mathrm{Sr}$, but it should be understood to include significant amounts of non-radioactive $\mathrm{Cs} / \mathrm{Sr}$ as well as barium and rubidium. Similarly the transition metal fission product elements will be referred to henceforth as TMFP, which also includes significant amounts of iron from ferrous sulfamate used to support the TRUEX extraction). Partitioning readily oxidized from readily reduced elements, enables consideration of several strategic options to take advantage of natural chemical and radiation characteristics:

1. A dedicated waste form of minimum volume containing the primary short-term heat producing isotopes ${ }^{137} \mathrm{Cs}$ and ${ }^{90} \mathrm{Sr}$ can be made for decay storage to dissipate heat prior to disposal. 
2. With regulatory change to the Nuclear Waste Policy Act ${ }^{5}$, after decay the $\mathrm{Cs} / \mathrm{Sr}$ waste form could possibly be disposed as LLW. Long-live ${ }^{135} \mathrm{Cs}$ content and cross-contamination with other isotopes such as TRU would also be considerations in this disposal concept. ${ }^{6}$

3. Readily oxidized elements including those in both the $\mathrm{Cs} / \mathrm{Sr}$ and $\mathrm{Ln}$ streams could be combined in one waste form with high waste loading limited by only thermal stability. These elements are very soluble in glass and waste loading would no longer be limited by noble metal solubility as is the case with high level wastes derived from traditional PUREX processing.

4. The transition metals could be chemically or electrochemically reduced from the nitrate solution TRUEX waste to elemental form. These metals could be combined with the UDS which are comprised of the same elements, and melted with additives, potentially waste fuel cladding and hardware to make a high-density alloy that is nearly $100 \%$ waste. ${ }^{2}$

The potential benefits of these options must be weighed against the additional costs of the additional processes as well as the FPEX process itself. This evaluation is a significant part of the trade-study covered in this report.

\section{TRADE-STUDY STRATEGIES}

Currently, the typical global waste form for HLW from the PUREX process is borosilicate glass containing waste elements as oxides. Unfortunately several fission product elements (primarily Mo and the noble metals $\mathrm{Ru}, \mathrm{Rh}, \mathrm{Pd}$ ) have limited solubility in glass, which results in low waste loading and requires production of more glass. Advanced separations coupled with matching the waste form to the target waste stream(s) chemistry allow the disposal system to achieve more optimum waste loading with comparable or improved performance. In theory, not only can the waste form be matched to the waste, but the disposal environment could also be matched. Some elements are more stable in a low oxygen reducing environment, while others are more stable as oxides. The simplest efficient combination of waste forms may be an oxidized form such as glass or ceramic for readily oxidized elements and a metallic form for readily reduced species. Thus, a more efficient waste management system that can make the most effective use of advanced waste forms and disposal design for each waste is enabled by advanced separations and how the waste streams are combined. This trade-study was designed to juxtapose a combined waste form baseline waste treatment scheme supporting advanced separations with two options and to evaluate the cost-benefit using available data from the conceptual design studies supported by DOE-NE.

The baseline to which the two options are compared is depicted in Figure 2. This waste treatment concept is an update from the baseline described in the IWMS reference. ${ }^{3,4}$ It makes maximum use of the potential for tailored waste forms matching waste stream chemistry and the disposal options enabled by advanced separations. It also requires certain specialized process steps to consider in the comparison. Specific points include:

1. Four separations processes.

2. Three waste immobilization processes producing three different waste forms.

a. A dedicated waste form for stabilizing the high-heat (generation) $\mathrm{Cs} / \mathrm{Sr}$ waste stream.

b. A new metal waste form similar to the metal waste form demonstrated for electrochemical reprocessing.

c. A low-heat (generation) glass (without $\mathrm{Cs} / \mathrm{Sr}$ ) similar to well characterized HLW glasses, but with a much greater waste fission product (Ln/TMFP) loading.

3. The potential option for disposal of the $\mathrm{Cs} / \mathrm{Sr}$ waste form as LLW pending decay. 


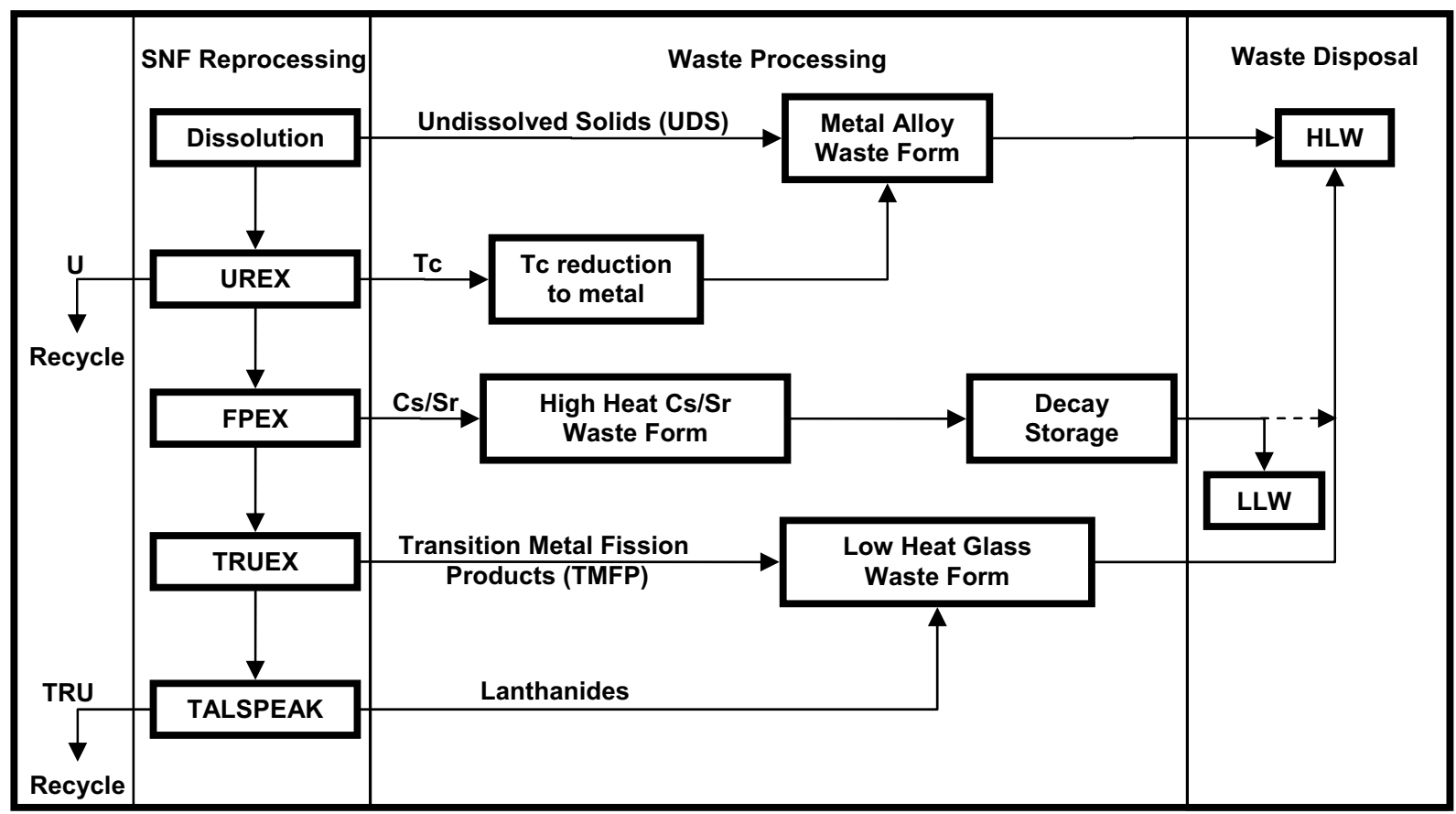

Figure 2. Combined waste form baseline waste treatment concept supporting advanced aqueous separations reprocessing.

The glass option (named based on the destination of the TMFP) is a simplification of the baseline in which the FPEX separation is abandoned, which also cancels the need for creating the dedicated high-heat $\mathrm{Cs} / \mathrm{Sr}$ waste form. Without FPEX, the alkali/alkaline earth elements are separated with the TMFP in TRUEX. Overall, this change has several positive and potentially negative impacts to consider:

1. Simplifies to three separations processes.

2. Simplifies to two waste immobilization processes producing two waste forms.

a. A glass waste form including $\mathrm{Cs} / \mathrm{Sr} / \mathrm{Ln} / \mathrm{TMFP}$ is similar to well-documented manufacture of HLW glasses, but with greater fission product waste loading.

b. Some significant process changes will probably be required for the relatively high-heat glass with much greater $\mathrm{Cs} / \mathrm{Sr}$ waste loading than traditional HLW glasses.

c. Same metal waste form proposed in Baseline, similar to the metal waste form demonstrated for electrochemical reprocessing.

d. Only two waste forms to qualify for repository disposal.

3. The option for disposal of the $\mathrm{Cs} / \mathrm{Sr}$ waste form as LLW pending decay is likely lost, and all wastes will probably be HLW.

A schematic depiction of this glass option with $\mathrm{Cs} / \mathrm{Sr} / \mathrm{Ln} / \mathrm{TMFP}$ in the oxide waste form is shown in Figure 3. 


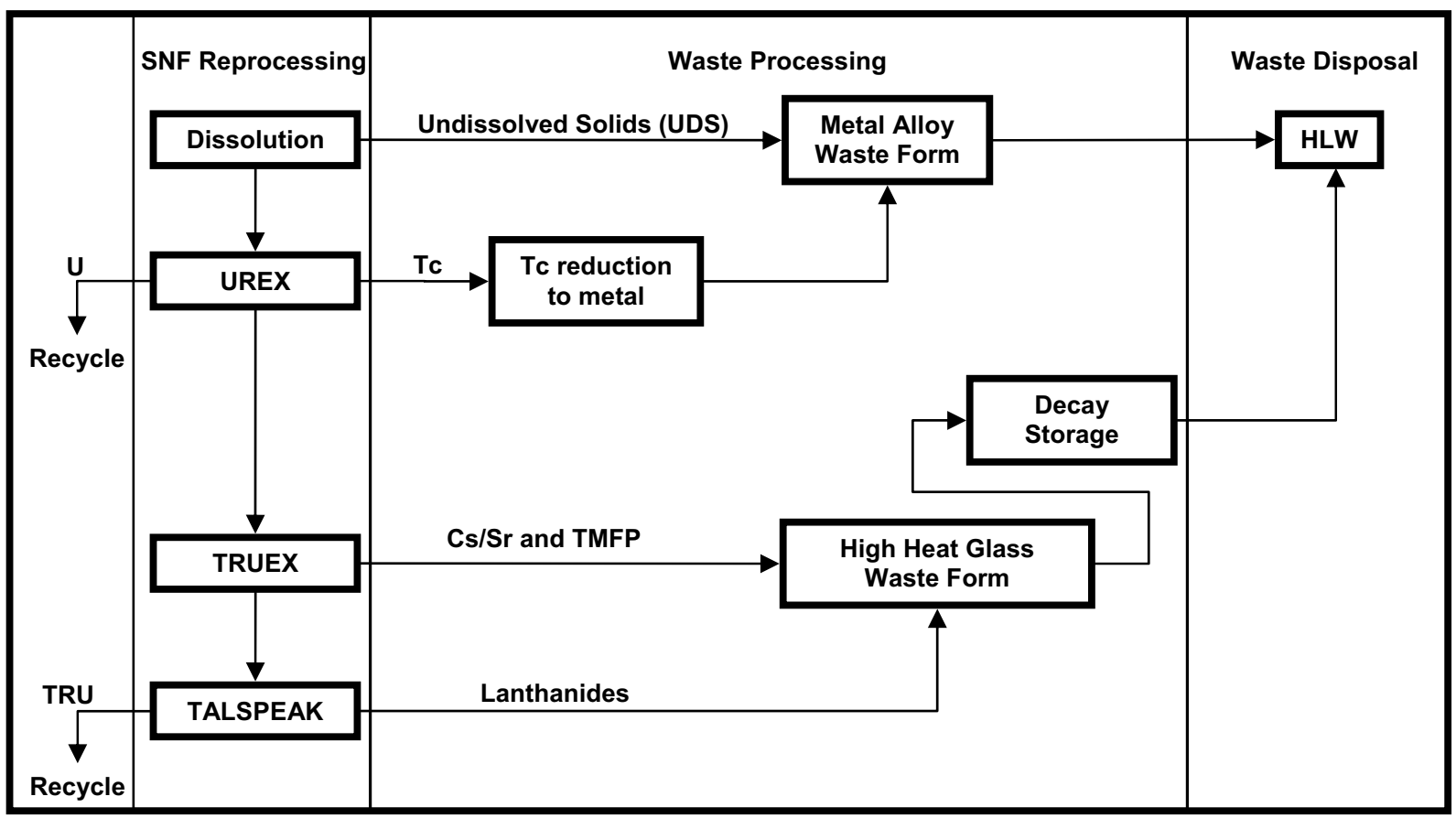

Figure 3. Glass option waste treatment concept with $\mathrm{Cs} / \mathrm{Sr} / \mathrm{Ln} / \mathrm{TMFP}$ in the oxide waste form.

The alloy option is actually somewhat more complex in waste preparation than the baseline because the FPEX separation is maintained and a new process is added to reduce the dissolved transition metals from the TRUEX separation to metallic elemental form (Figure 4). Rather than producing the dedicated very high-heat $\mathrm{Cs} / \mathrm{Sr}$ waste form, a relatively lower power (still high-heat compared to the baseline and traditional HLW glass) combined Cs/Sr/Ln glass is made. The metallic TMFP are then added to the $\mathrm{Tc} /$ UDS alloy, making a very high density waste form that could be essentially all waste material if the additives needed are supplied by waste fuel cladding and hardware. The major benefit to this concept is that similar to the glass option only two waste forms are made, and in addition, by combining all of the metals in one form the volume is greatly reduced. Overall, this concept has several positive and potentially negative impacts to consider:

1. Maintains the need for four separations processes.

2. Simplifies to two waste immobilization processes producing two waste forms.
a. A glass waste form including $\mathrm{Cs} / \mathrm{Sr} / \mathrm{Ln}$ is similar to well-documented manufacture of HLW glasses.
b. Some significant process changes will probably be required for the relatively high-heat glass with much greater $\mathrm{Cs} / \mathrm{Sr}$ waste loading than traditional HLW glasses.
c. A new metal waste form is proposed, similar to the metal waste form demonstrated for electrochemical reprocessing, but now requiring a significant reduction step applied to a significant TRUEX waste volume.

d. Only two waste forms to qualify for repository disposal.

3. A significant benefit to this concept is that the glass is made without the transition metals namely Mo, and the noble metals $(\mathrm{Ru}, \mathrm{Rh}, \mathrm{Pd})$ that restrict waste loading due to their very low solubility. This allows a much greater waste loading in the glass. Combined with the high-density, high waste-loading alloy waste form, this concept minimizes the total HLW volume over all other waste management concepts. 
4. The option for disposal of the $\mathrm{Cs} / \mathrm{Sr}$ waste form as LLW pending decay is likely lost, and all wastes will probably be HLW. However, the potential for considering a combined $\mathrm{Cs} / \mathrm{Sr} / \mathrm{Ln}$ waste form as LLW should be investigated under a possible expansion of 10CFR 61.

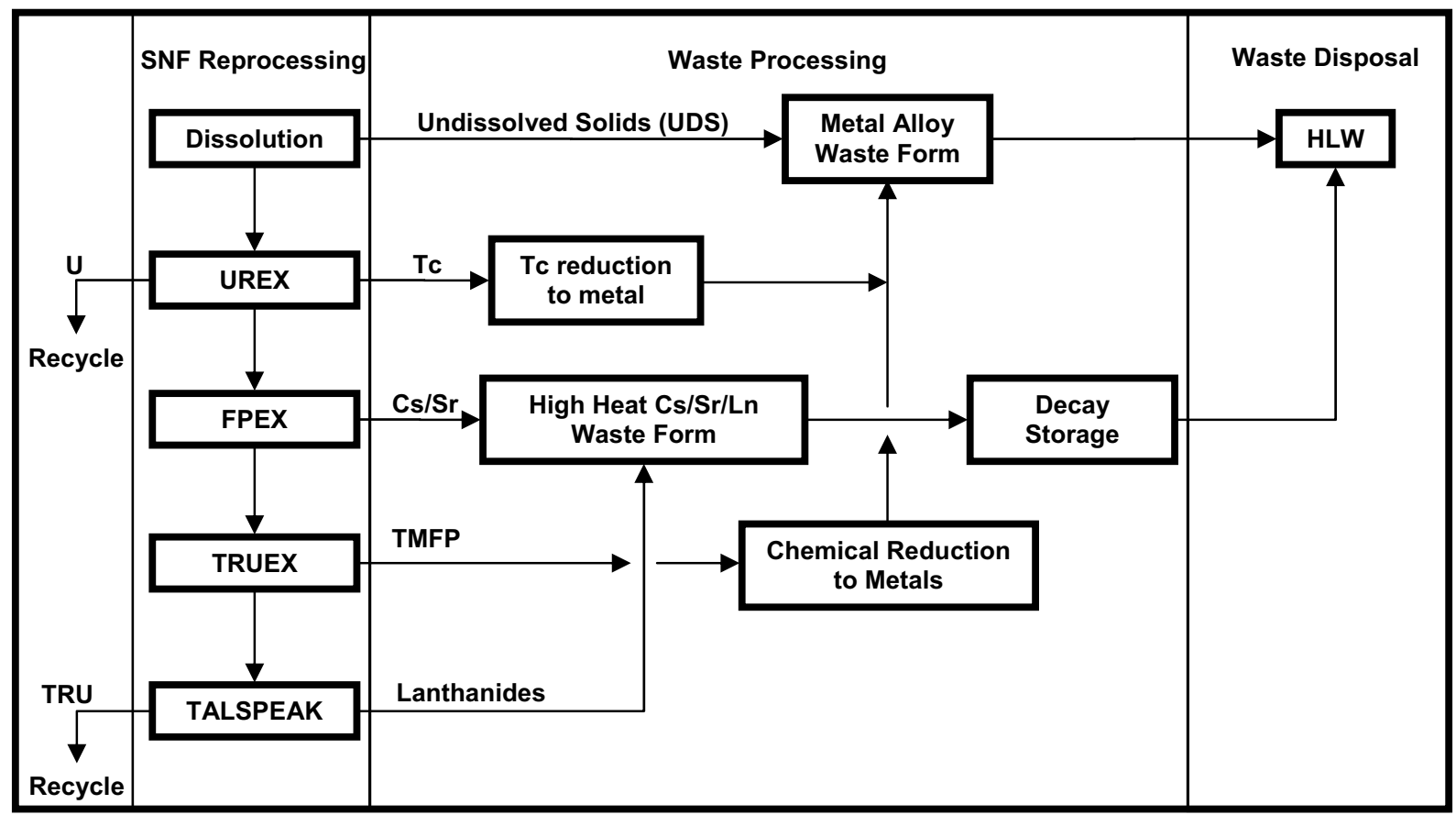

Figure 4. Alloy option waste treatment concept with $\mathrm{Cs} / \mathrm{Sr} / \mathrm{Ln} / \mathrm{TMFP}$ in the oxide waste form and the $\mathrm{UDS} / \mathrm{Tc} / \mathrm{TMFP}$ in a metal alloy.

\section{APPROACH}

To comprehensively evaluate the options described above would require significant funding to produce conceptual designs for facilities based on the three process schemes. However, the concepts can be compared on a relative basis by using a preliminary conceptual design for the baseline and then adding or subtracting the capital and operating costs for modules needed or deleted to fit the option schematics. The supporting data is rough order-of-magnitude, but it should suffice to indicate whether a design option is likely to be relatively more or less cost-effective. The module manipulation can be largely inferred from the descriptions for the schemes. A summary is provided in Figure 5, including:

\section{Additions:}

1. High-heat Glass - a process module based on existing HLW glass production with an added relatively small allowance for additional costs to produce glass using high-heat wastes. Costs are incurred to manage solutions that produce appreciable heat per unit volume which may require cooling and greater radioactivity requiring additional shielding.

2. TMFP reduction - chemical or electrochemical reduction of transition metal elements dissolved in nitric acid to form elemental metals, preparation for addition to a metal melter, and modification of the baseline system for the Tc/UDS alloy waste form to include the additional TMFP metals from the TRUEX separation. This process must have a fairly significant capacity to accommodate the wastes from TRUEX that include appreciable cold chemical additives such as ferrous sulfamate. 
Reductions:

1. FPEX extraction - the FPEX separation process is a significant module in the separations facility involving many centrifugal contactors in a hot cell.

2. $\mathrm{Cs} / \mathrm{Sr}$ dedicated waste form - a glass or ceramic process to convert this extremely radioactive, highheat waste into a solid. Self-heating solutions and high radiation levels combine to make this process fairly complex and a significant addition to an advanced separations facility.

3. Low-heat glass - a significant process module based on existing HLW glass production

\section{Glass Option Alloy Option}

Addition

Baseline \$

-UREX+1a

- Cs/Sr Waste Form

-Low Heat Ln/TMFP Glass

-Tc/UDS alloy

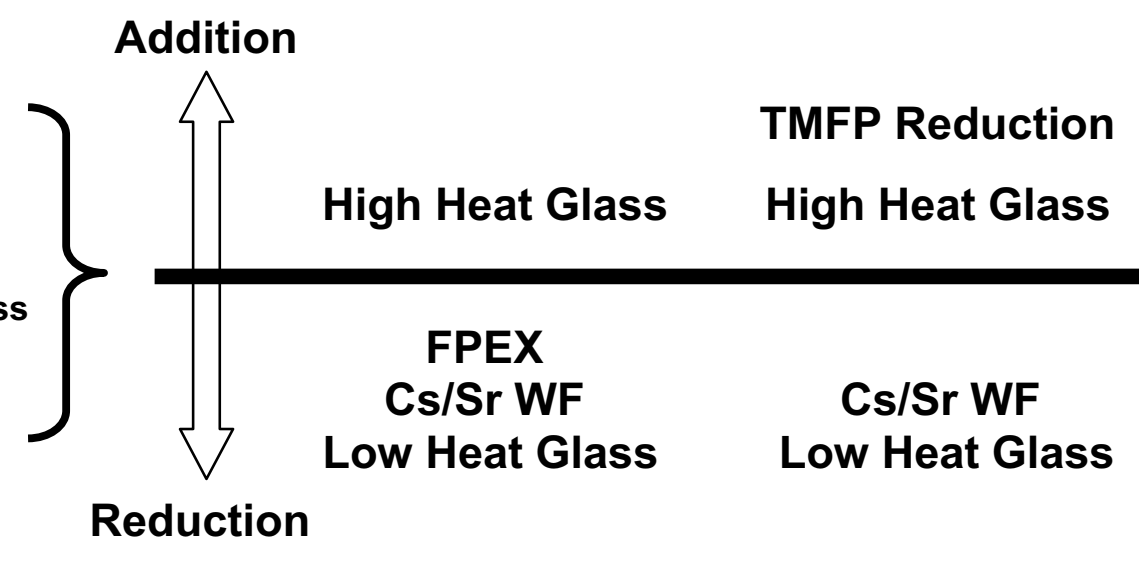

Figure 5. Summary of cost module addition and reductions to make relative comparison.

\section{ASSUMPTIONS}

1. The balance of the facility modules including the UREX, TRUEX, TALSPEAK separations, waste stabilization processes, and supporting facilities including offgas treatment, secondary waste handling, and plant support are all assumed to be fairly comparable and were not considered discriminating costs in the comparison.

2. Any waste containing $\mathrm{Cs} / \mathrm{Sr}$ can be stored sufficiently long (nominally 100 years) to allow it to decay to a power level allowable for placement in a repository, thus waste loading is limited only by solubility of all constituents in the combined waste streams or by the thermal stability of the waste form, whichever is most limiting.

3. High level waste disposal cost is set on a canister unit cost basis, regardless of the diameter or weight of the canister and includes transportation, placement in the repository and all supporting functions beyond the reprocessing facility. Canister size and capacity is calculated as described in Section 6.

4. All separations are $100 \%$ efficient.

5. Spent fuel composition is based on Origen calculations for $51 \mathrm{GWd} / \mathrm{MTHM}, 20$ years cooled.

6. Waste loading and density information were provided by John Vienna, PNNL and Bill Ebert, ANL resulting in waste form volumes per MTHM processed as shown in Table 2. Note that these waste forms are developmental, and expected waste loading and waste form densities are actually greater 
than the estimated waste loading ranges published earlier. ${ }^{3}$ Values used for this study used the bestcase, most advantageous values updated from the IWMS Baseline report to evaluate the cost-benefit of advanced waste forms in terms of their maximum expected benefit. Thus, the base case presented here is for the purposes of this study alone and does not compare directly to previously published references.

Table 2. Waste Stream Mass, and Stabilized Waste Form Data.

\begin{tabular}{|l|l|c|c|c|c|c|}
\hline \multirow{2}{*}{$\begin{array}{c}\text { Waste } \begin{array}{c}\text { Form } \\
\text { Matrix }\end{array} \\
\text { Glass }\end{array}$} & Waste Stream & $\begin{array}{c}\text { Mass of } \\
\text { untreated } \\
\text { waste* }\end{array}$ & $\begin{array}{c}\text { Waste Form } \\
\text { Density }\end{array}$ & $\begin{array}{c}\text { Waste } \\
\text { Loading }\end{array}$ & $\begin{array}{c}\text { Waste Form } \\
\text { Mass** }\end{array}$ & $\begin{array}{c}\text { Waste } \\
\text { Volume*** }\end{array}$ \\
\cline { 2 - 7 } & $\mathrm{kg} / \mathrm{MTHM}$ & $\mathrm{MT} / \mathrm{m}^{3}$ & $\mathrm{Wt} \%$ & $\mathrm{Kg} / \mathrm{MTHM}$ & $\mathrm{m}^{3} / \mathrm{MTHM}$ \\
\hline & $\mathrm{CsSr}$ & 64 & 2.8 & $40 \%$ & 161 & $5.69 \mathrm{E}-02$ \\
\hline & $\mathrm{CsSr} / \mathrm{Ln}$ & 27 & 3.7 & $50 \%$ & 55 & $1.47 \mathrm{E}-02$ \\
\hline & $\mathrm{CsSr} / \mathrm{Ln} / \mathrm{TMFP}$ & 73 & 2.7 & $45 \%$ & 161 & $5.99 \mathrm{E}-02$ \\
\hline Metal & $\mathrm{UDS} / \mathrm{TC}$ & 11 & 8.0 & $39 \%$ & 28 & $3.46 \mathrm{E}-03$ \\
\hline \multicolumn{7}{|l|}{} \\
\hline
\end{tabular}

\section{HIGH LEVEL WASTE DISPOSAL COSTS}

\subsection{Disposal Comparison by Volume only}

Estimating the unit volume cost of disposal for HLW is not simple and varies significantly depending, among other things, on what costs are included (e.g. repository development, transportation, placement, closure, etc.). The most current reference is probably from DOE-RW, "The Analysis of the Total System Life Cycle Cost (TSLCC) of the Civilian Radioactive Waste Management Program," which presents the Office of Civilian Radioactive Waste Management's (OCRWM or DOE-RW) May 2007 total system cost estimate for the disposal of the Nation's spent nuclear fuel (SNF) and high-level radioactive waste (HLW). ${ }^{7}$ A simplistic estimate can be made on a mass basis using the TSLCC in 2007 dollars, or \$96B for disposal of $122,100 \mathrm{MTHM}$ or $\$ 790 \mathrm{~K} / \mathrm{MTHM}$. Knowing that $\sim 90 \%$ of the material to be disposed is commercial fuel, with the balance a mixture of government owned SNF and HLW, this value is unlikely to be representative of the value of an incremental change to the disposal volume of stabilized HLW as would be realized with reprocessing and use of advance waste forms. However, it does establish the order-of-magnitude in potential savings, based on the current repository design if all calculations are kept on a basis of MTHM. Certainly the repository development costs, siting studies, and license support cannot readily be allocated to future activities supporting waste placement or incremental savings in waste volume. On the contrary, estimating potential savings in not siting or postponing an additional repository due to savings in waste volume are also problematic.

In an effort to tie the cost more directly to waste volume, reference must be made to the Yucca Mountain Science and Engineering Report. ${ }^{8}$ As illustrated in Figure 6, the Yucca Mountain design disposal concept uses SNF only and SNF/HLW disposal packages for disposal in a repository drift (tunnel). 


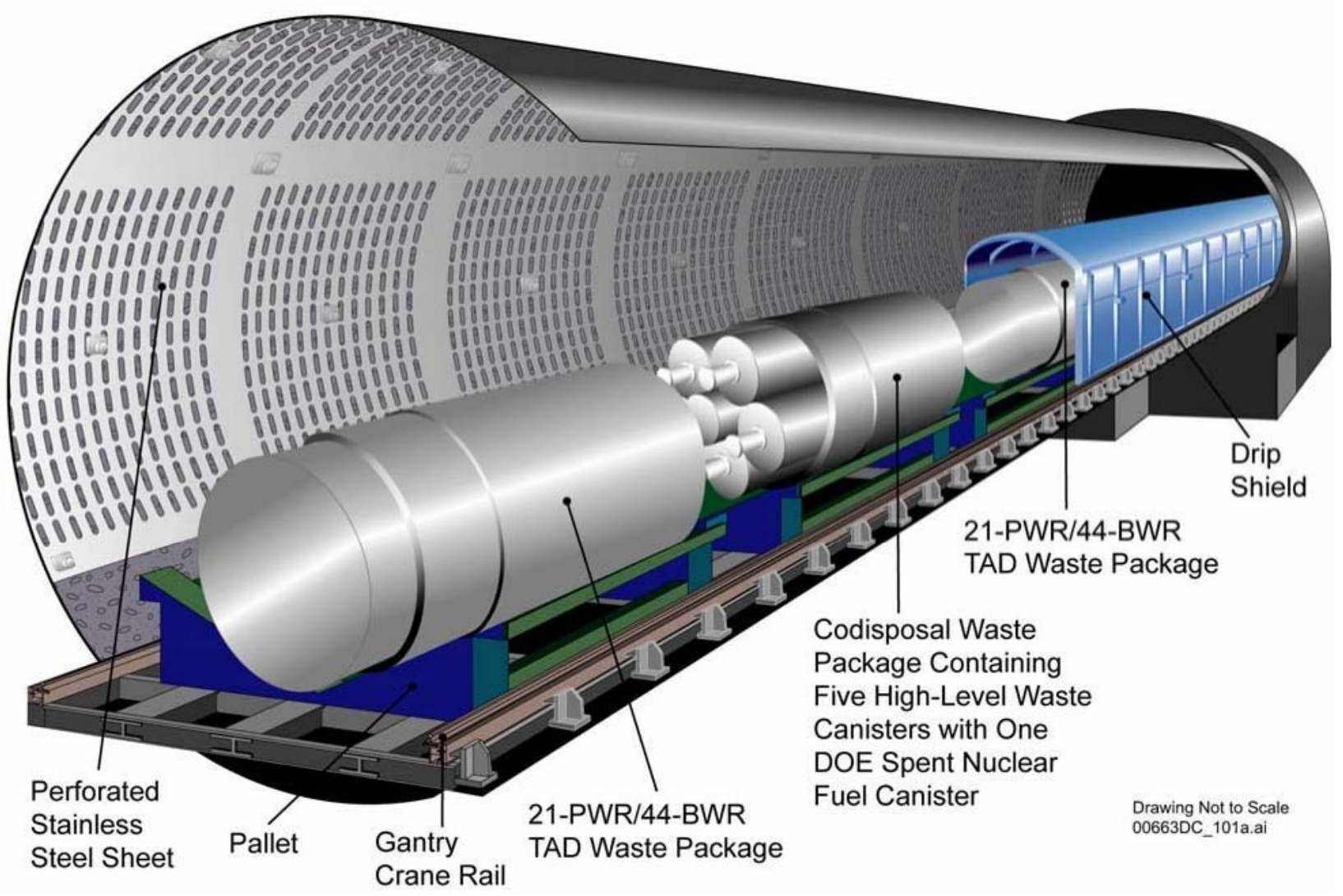

Figure 6. Schematic Illustration of the Emplacement Drift with Cutaway Views of Different Waste Packages.

One can see from Figure 6, commercial PWR/BWR SNF is disposed in dedicated packages, and government HLW is co-disposed in a package containing a circular array with five HLW canisters around one slightly smaller diameter canister containing government-owned SNF. The packages are disposed linearly on a rail system. Using this configuration as a basis, a correlation can be made between waste volume and repository space allocation in rail length (meters) whether the disposal package contains SNF (MTHM) or HLW (MTHM equivalent, or volume $\mathrm{m}^{3}$ ).

First, considering commercial direct disposal only, fuel is containerized in a transportation and disposal container (TAD), which is then contained in a waste package for disposal. The TAD is about $5.5 \mathrm{~m}$ $(18 \text { feet })^{9}$ long but the waste packages are nominally $5.85 \mathrm{~m}$ (19 feet) long including a shielding plug. ${ }^{10}$ Assuming that fuel is stored sufficiently long to allow decay such that canisters meet repository heat limits, the packages can then be placed end to end with negligible space between them. The storage efficiency in terms of lineal meters of drift per MTHM disposed can be estimated as follows:

- A single TAD capacity for PWR fuel is 21 elements. ${ }^{10}$ At $460 \mathrm{~kg}$ heavy metal per PWR assembly ${ }^{11}$ this totals 9.66 MTHM for a disposal efficiency of 9.66 MTHM / $5.85 \mathrm{~m}=1.65 \mathrm{MTHM} / \mathrm{m}$

- A single TAD capacity for BWR fuel is 44 elements. ${ }^{10}$ At $180 \mathrm{~kg}$ heavy metal per BWR assembly ${ }^{11}$ this totals 7.92 MTHM for a disposal efficiency of $7.92 \mathrm{MTHM} / 5.85 \mathrm{~m}=1.35 \mathrm{MTHM} / \mathrm{m}$

- Using the $8 / 5$ ratio of PWR/BWR fuel in the current SNF legacy ${ }^{7}$ inventory as a basis for averaging, a nominal disposal efficiency using the current design basis is $1.54 \mathrm{MTHM} / \mathrm{m}$ or conversely $0.66 \mathrm{~m} / \mathrm{MTHM}$ 
- Volume is not as useful as disposal length, but is frequently a parameter of interest. For comparison, a SNF waste package is $1.96 \mathrm{~m}$ (6.4 feet) in diameter for a total volume of $17.6 \mathrm{~m}^{3}$. Thus, the packing volume for SNF is the average (8/5 ratio) capacity of a package or $9.0 \mathrm{MTHM} /$ package $/ 17.6 \mathrm{~m}^{3}=$ $0.51 \mathrm{MTHM} / \mathrm{m}^{3}$ or $1.97 \mathrm{~m}^{3} / \mathrm{MTHM}$

A similar analysis can be done for potential HLW forms. As described above, the current design for HLW disposal is to combine one government SNF canister with five HLW canisters in a waste package. These canisters are nominally 10 or 15 feet long, but for comparison purposes, we assume here (only) that they are the same length as SNF TADs $(5.5 \mathrm{~m})$ contained in $5.65 \mathrm{~m}$ waste packages. Mathematically the overall length per package should not matter because we are assuming sufficient cooling to allow the packages to be placed end to end, essentially creating a continuous cylinder. For this analysis, it is assumed that the comparison can be normalized to unit length regardless of the individual package length. If it is assumed that all HLW can be combined conveniently in similar packages with no limitation other than volume, the results are as follows:

- Combined waste form base case, with three waste forms, stabilized Cs/Sr $\left(6.46 \mathrm{E}-03 \mathrm{~m}^{3} / \mathrm{MTHM}\right)+$ Tc/UDS (3.46E-03 m³/MTHM) + Ln/TMFP (5.69E-02 $\left.\mathrm{m}^{3} / \mathrm{MTHM}\right)=6.69 \mathrm{E}-02 \mathrm{~m}^{3} / \mathrm{MTHM}$ (From Table 2)

- Assuming $100 \%$ full canisters $0.61 \mathrm{~m}$ (two feet) diameter x $5.5 \mathrm{~m}$ (18 feet) long, the capacity of one canister is $1.6 \mathrm{~m}^{3}$, and a six canister array in a waste package would hold $9.61 \mathrm{~m}^{3}$

- In terms of HLW volume equivalence to processed SNF, one waste package would hold the equivalent of 9.61/6.69E-02 $=144 \mathrm{MTHM} /$ package or $(144 \mathrm{MTHM}) /(5.85 \mathrm{~m})=24.6 \mathrm{MTHM} / \mathrm{m}$

- Thus reprocessing, using the baseline waste forms could accomplish a disposal efficiency gain of 24.6/1.54 = 16 fold improvement versus direct disposal of SNF, considering only volume.

Similar manipulation can be applied to the glass and alloy options. Considering next the glass option with two waste forms:

- $\mathrm{Tc} / \mathrm{UDS}\left(3.46 \mathrm{E}-03 \mathrm{~m}^{3} / \mathrm{MTHM}\right)+\mathrm{Cs} / \mathrm{Sr} / \mathrm{Ln} / \mathrm{TMFP}\left(5.99 \mathrm{E}-02 \mathrm{~m}^{3} / \mathrm{MTHM}\right)=6.34 \mathrm{E}-02 \mathrm{~m}^{3} / \mathrm{MTHM}$

- A waste package would hold the equivalent of 9.61/6.34E-02 = $152 \mathrm{MTHM} /$ package or (152 MTHM) $/(5.85 \mathrm{~m})=25.9 \mathrm{MTHM} / \mathrm{m}$

- The glass option could accomplish a disposal efficiency gain of 25.9/1.54 = 17 fold volume improvement versus direct disposal of SNF

Finally, the alloy option with two waste forms:

- $\mathrm{Tc} / \mathrm{UDS} / \mathrm{TMFP}\left(6.55 \mathrm{E}-03 \mathrm{~m}^{3} / \mathrm{MTHM}\right)+\mathrm{Cs} / \mathrm{Sr} / \mathrm{Ln}\left(1.47 \mathrm{E}-02 \mathrm{~m}^{3} / \mathrm{MTHM}\right)=2.13 \mathrm{E}-02 \mathrm{~m}^{3} / \mathrm{MTHM}$

- A waste package would hold the equivalent of 9.61/2.13E-02 $=451 \mathrm{MTHM} /$ package or (451 MTHM) $/(5.85 \mathrm{~m})=77.1 \mathrm{MTHM} / \mathrm{m}$

- The alloy option could accomplish a disposal efficiency gain of 77.2/1.54 = 51 fold volume improvement versus direct disposal of SNF

A summary of these results is shown in Table 3, with the relative disposal efficiencies for each option. 
Table 3. Summary of comparison of disposal volume relative to direct disposal of SNF.

\begin{tabular}{|l|c|c|c|c|c|}
\hline \multicolumn{1}{|c|}{ Case } & Forms & Volume & Reduction vs SNF & Length & Reduction vs SNF \\
\cline { 3 - 6 } & $\mathrm{m}^{3} /$ MTHM & Simple Vol Ratio & MTHM/m & $\begin{array}{c}\text { Packaged Disposal } \\
\text { Length Ratio }\end{array}$ \\
\hline $\begin{array}{l}\text { Direct } \\
\text { SNF }\end{array}$ & 1 & 1.97 & 1 & 1.54 & 1 \\
\hline Base Case & 3 & 0.067 & 29 & 24.6 & 16 \\
\hline Glass & 2 & 0.063 & 31 & 25.9 & 17 \\
\hline Alloy & 2 & 0.021 & 94 & 77.2 & 51 \\
\hline
\end{tabular}

\subsection{Mass Constraints on HLW Disposal}

The above simple comparison based on volume alone showed the maximum disposal efficiency attainable using the waste forms under consideration. This is complicated in practice because the maximum length and mass of a full HLW canister is limited to $4.5 \mathrm{~m}^{10}$ (15 feet) and 4,200 kg. ${ }^{12}$ An empty canister weighs about $700 \mathrm{~kg},{ }^{10}$ so the maximum canister capacity is about $3500 \mathrm{~kg}$. Also, canisters are only filled about $90 \%$ full to prevent overflow, reducing the working volume to about $1.18 \mathrm{~m}^{3}$. Thus waste forms with a density greater than $3500 \mathrm{~kg} / 1000 \mathrm{~kg} / \mathrm{MTHM} / 1.18 \mathrm{~m}^{3} \sim 3 \mathrm{MT} / \mathrm{m}^{3}$ will be weight limited. The estimated densities of the waste forms, with the resultant maximum canister fill percentage are summarized in Table 4.

Table 4. Summary of waste form densities and allowable fill efficiencies for standard $0.61 \mathrm{~m}$ diameter, $4.5 \mathrm{~m}$ long waste canisters.

\begin{tabular}{|l|c|c|}
\hline \multicolumn{1}{|c|}{ Waste Form } & $\begin{array}{c}\text { Density } \\
\text { MT/m3 }\end{array}$ & $\begin{array}{c}\text { Maximum Fill } \\
\%\end{array}$ \\
\hline Glass - Ln/TMFP & 2.8 & $100 \%$ \\
\hline Glass - CsSr & 3.4 & $87 \%$ \\
\hline Glass - CsSr/Ln & 3.7 & $78 \%$ \\
\hline Glass - CsSr/Ln/TMFP & 2.7 & $100 \%$ \\
\hline Alloy - UDS/Tc & 8.0 & $37 \%$ \\
\hline Alloy - UDS/Tc/TMFP & 8.0 & $37 \%$ \\
\hline$* 1.18 \mathrm{~m}^{3}$ canister volume with capacity of $3500 \mathrm{~kg}$. & \\
\hline
\end{tabular}

Thus, based on a waste package design holding six canisters per package, the actual disposal efficiency is reduced from the values shown above due to the density of the waste forms. Either the canisters are not filled completely with waste, or the packages for some wastes are made smaller. Rather than computing the disposal efficiency discounting for the weight limit, in the next section the maximum container size is estimated based on decay heat to determine which is the limiting constraint.

\subsection{Thermal Constraints on HLW Disposal}

Modeling based on the Yucca Mountain repository design has examined the effects of decay heat and postulated the potential benefits of advanced separations and managing the various waste streams. ${ }^{13,14} \mathrm{In}$ essence, by segregating the radionuclides with greatest heat generation and managing them effectively, e.g. burning the actinides in a reactor and allowing the short-lived fission products to decay, additional waste could be placed in the same space without exceeding the thermal design limits. However, attaining this goal relies on either making more efficient use of the repository space (additional waste could be 
placed in the same space) or making more space for the additional waste. As shown above, based on volume alone, reprocessing results in a theoretical benefit of $\sim 94 \mathrm{x}$ (HLW equivalent to processing $94 \mathrm{x}$ the mass of heavy metal as SNF), but packaging and the linear disposal system reduces the benefit to $\sim 51 \mathrm{x}$. As shown later this may also be limited further by allowable container weight.

Just as a repository is likely to be limited by heat in any geology, a waste form is also subject to thermal stability limits. The alkali/alkaline earth elements are very soluble in glass; it is possible to add so much radioactive $\mathrm{Cs} / \mathrm{Sr}$ to glass that it causes it to exceed the glass transition temperature, allowing it to crystallize, thereby altering the waste form. The lanthanides also contribute decay heat, though at a much lesser rate. Canister size must therefore be limited based on waste loading, and total thermal output rate (power). Based on fuel burnup and age since removal from the reactor, the radioactivity and decay energy of each radionuclide can be summed to estimate the power output of each waste stream. The decay heat from different waste streams can then be summed to represent combined wastes. The heat output $q$ in watts $/ \mathrm{m}^{3}$ generated homogeneously throughout the waste form can then be estimated.

Referring to Figure 7, heat is conducted radially to the cylindrical surface based on the difference between the centerline temperature $\mathrm{T}_{\mathrm{C}}$ and the waste container surface temperature $\mathrm{T}_{\mathrm{S}}$ at a rate correlated to the waste form thermal conductivity $\mathrm{k}(\mathrm{W} / \mathrm{m} / \mathrm{K})$. From the canister surface heat is lost to the environment primarily by convection as air flows up through the cylindrical vault in which the canister is placed. Heat loss is proportional to the temperature difference between the canister surface $\mathrm{T}_{\mathrm{S}}$ and the nominal air temperature $\mathrm{T} \infty$ as a rate correlated to the convective heat transfer coefficient $\mathrm{h}(\mathrm{W} / \mathrm{m} 2 / \mathrm{K})$. Heat can also be lost radiantly from the canister surface and radiated back by the vault, but for simplicity it is assumed here that the canister and wall surfaces are in near equilibrium and net radiant losses are negligible. Similarly, there are conductive and convective heat losses from the container bottom and top respectively, but these are assumed to be negligible in comparison to the convective losses with free flow of ventilation air. For a known heat output $\mathrm{q}$ and glass thermal conductivity $\mathrm{k}$ and estimating the convective heat transfer coefficient $h$, the maximum allowable canister diameter can be estimated to limit the centerline temperature to the maximum allowable $\mathrm{T}_{\mathrm{G}}$ without crystallizing the glass waste form. The solution to this heat transfer model was calculated for the waste forms at maximum waste loading using a finite element model by Mike Kaminski at Argonne National Laboratory. A simplified analytical solution for a heat generating cyclinder ${ }^{15}$ was also programmed into a spreadsheet sacrificing some precision for speed and the ability to conduct sensitivity tests varying the waste loading, which varies the heat rate $\mathrm{q}$. The simplified expression is shown below:

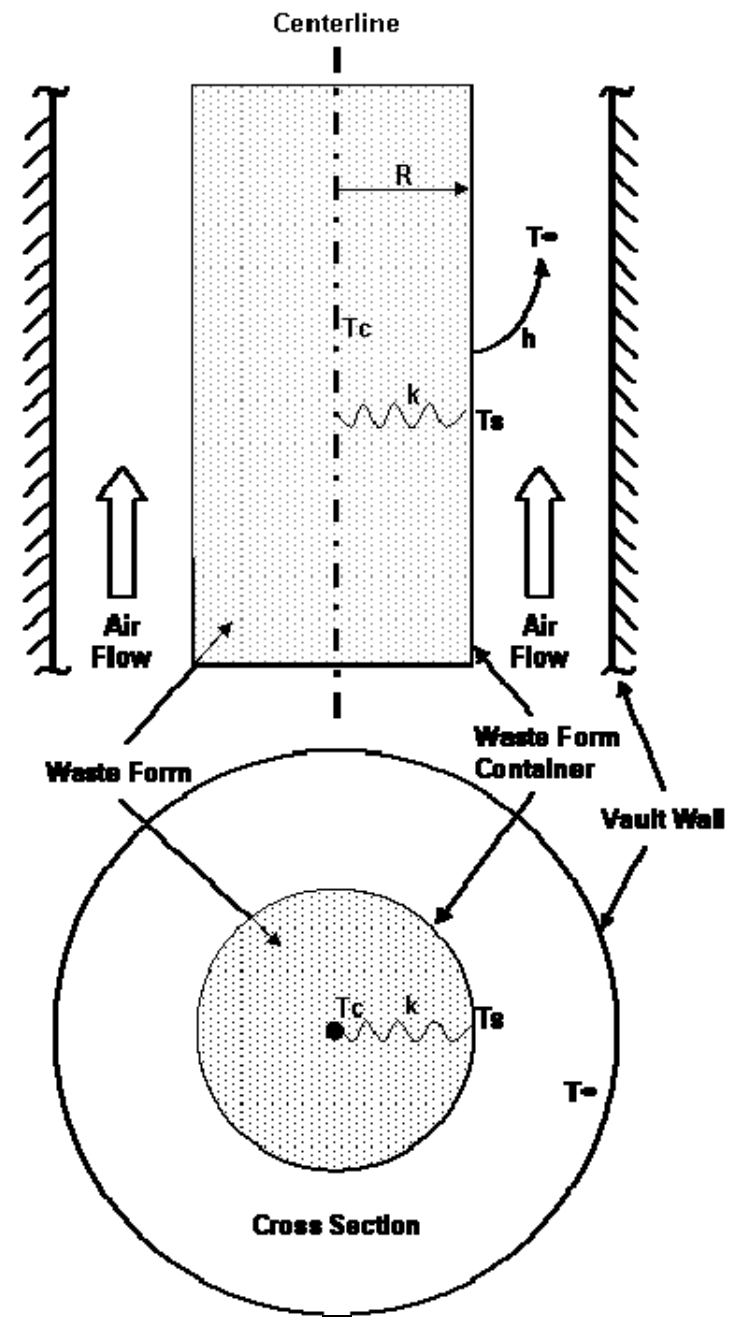

Figure 7. Conceptual heat transfer model for waste canister in storage vault. 
$\mathrm{q}\left(\mathrm{W} / \mathrm{m}^{3}\right)=4 \mathrm{x}[(\mathrm{T}$ centerline $)-(\mathrm{T}$ air $)] /\left[\mathrm{r}^{2} / \mathrm{k}+2 \mathrm{r} / \mathrm{h}\right]$, where $\mathrm{r}$ is radius $(\mathrm{m}), \mathrm{k}(\mathrm{W} / \mathrm{m} / \mathrm{K}), \mathrm{h}\left(\mathrm{W} / \mathrm{m}^{2} / \mathrm{K}\right)$

This can be rearranged as:

$\mathrm{r}^{2} / \mathrm{k}+2 \mathrm{r} / \mathrm{h}-4 \mathrm{x}\left[(\mathrm{T}\right.$ centerline $)-\left(\mathrm{T}_{\mathrm{s}}\right.$ air $\left.)\right] / \mathrm{q}=0$

and solved for $r$ directly using the quadratic equation $: r=\left\{(-2 / \mathrm{h}) \pm \operatorname{sqrt}\left[\left(4 / \mathrm{h}^{2}\right)+(4 / \mathrm{k}) \mathrm{x}\left(4 \mathrm{x}\left(\mathrm{T}_{\mathrm{c}}-\mathrm{T}_{\mathrm{s}}\right) / \mathrm{q}\right]\right\} /(2 / \mathrm{k})\right.$

A summary of results for the finite element analysis and the similar values from the analytical solutions using the same assumptions are summarized in Table 5.

Table 5. Glass ${ }^{*}$ canister maximum diameter to maintain centerline temperature $\mathrm{T}_{\mathrm{C}}<\left(\mathrm{T}_{\mathrm{G}} \mathrm{x} 0.9\right)^{* *}$

\begin{tabular}{|c|c|c|c|c|c|c|c|}
\hline Glass & $\begin{array}{c}\text { Waste } \\
\text { Loading } \\
\mathrm{wt}^{0} \%\end{array}$ & $\begin{array}{c}\text { Power }^{* * *} \\
\mathrm{q} \\
\mathrm{W} / \mathrm{m}^{3} \\
\end{array}$ & $\begin{array}{c}\mathrm{T}_{\mathrm{C}^{* *}} \\
\max { }^{2} \\
\mathrm{C} \\
\end{array}$ & $\begin{array}{c}\text { Analytical } \\
\text { Radius } \\
\text { m }\end{array}$ & $\begin{array}{c}\text { Finite Elem } \\
\text { Radius } \\
\text { m }\end{array}$ & $\begin{array}{c}\text { Radius for } \\
\text { Study } \\
\text { m } \\
\end{array}$ & $\begin{array}{c}\text { Power per } \\
\text { Canister } \\
\mathrm{kW} \\
\end{array}$ \\
\hline $\mathrm{CsSr}$ & $40.0 \%$ & 144160 & 603 & 0.08 & 0.09 & 0.08 & 12 \\
\hline $\mathrm{CsSr} / \mathrm{Ln}$ & $50.0 \%$ & 65417 & 616 & 0.13 & 0.16 & 0.13 & 16 \\
\hline $\mathrm{CsSr} / \mathrm{Ln} / \mathrm{TMFP}$ & $45.3 \%$ & 16098 & 423 & 0.23 & 0.23 & 0.23 & 12 \\
\hline \multicolumn{8}{|c|}{$\begin{array}{l}{ }^{*} \text { Only the glasses are thermally limited, the radionuclides in the metal alloy generate very little heat } \\
{ }^{* *} \text { The canister size was limited to maintain the centerline temperature at } 10 \% \text { less than the glass transition temperature in } \\
\text { degrees Kelvin. } \\
{ }^{* * *} \text { Spent fuel composition is based on Origen calculations for } 51 \mathrm{GWd} / \mathrm{MTHM}, 20 \text { years cooled. }\end{array}$} \\
\hline
\end{tabular}

Note that all of the canisters containing $\mathrm{Cs} / \mathrm{Sr}$ are heat limited at these waste loadings (diameter $<0.61 \mathrm{~m}$ ). The maximum power output from a SNF package in the repository is limited to $25 \mathrm{~kW}$. Under the current design constraints, a waste package containing six of the CsSr/Ln waste canisters sized as in Table 5 would take 116 years of decay to meet the repository limit (based on a nominal half-life of 30 years). This could conceivably be accomplished with some combination of staged cooling outside the repository and forced ventilation inside the repository. The specific heat output per kilogram is greater for the $\mathrm{CsSr}$ glass and lesser for the CsSr/Ln/TMFP glass, but their cooling times are similar at about 105 years because of the differences in allowable canister size.

\subsection{Estimating Potential Savings in HLW Costs}

The results from these three evaluations of HLW disposal quantity by volume, mass, and heat is that the traditional quantification of HLW by total volume or mass is insufficient to understand the incremental disposal costs and potential savings that could result from using advanced separations and tailored waste forms. With metal waste forms limited by mass and glass waste forms limited by heat, the only common basis that can be compared to containerized SNF is the number of packages that must be transported, handled, and placed. The HLW disposal costs estimated for the repository downstream of the reprocessing plant do not correlate with waste mass or volume just as they do not vary directly whether the commercial SNF packages contain PWR or BWR fuel. Only the number of packages affects operations and lineal disposal space in a drift. Therefore, disposal costs should be allocated by waste package. Returning to the Yucca Mountain TSLCC in 2007 dollars, or \$96.2B, this covers repository operations (including transportation) for 17,450 waste packages ${ }^{7}$ (commercial SNF and government $\mathrm{SNF} / \mathrm{HLW}$ ), or $\$ 5.51 \mathrm{M}$ per package ( $\$ 920 \mathrm{~K}$ per canister). One could argue that $\$ 13.5 \mathrm{~B}$ of the TSLCC has been spent on repository characterization and license development, and therefore only future costs ( $\$ 82.6 \mathrm{~B}$ ) should be apportioned to SNF/HLW disposal, or $\$ 790 \mathrm{~K} /$ canister. For the purposes of this 
analysis a value of $\$ 850 \mathrm{~K} /$ canister was used, and sensitivity studies were conducted to determine the effects of varying the value up or down.

The contrast between the baseline waste management strategy and the two options is stark whether one compares based on total volume or total canisters as shown in Figures 8 and 9. Figure 8 shows the relative total volumes of HLW for each option per MTHM processed, broken down by alloy, low-heat glass (no $\mathrm{CsSr}$ ), and high-heat glass (with $\mathrm{Cs} / \mathrm{Sr}$ ). Note that when evaluated using the traditional metric of total volume the third option (alloy) is clearly the most attractive. The glass option uses only two waste form processes, which is attractive compared to the base case which uses three, but from a volume perspective, there is very little benefit. Also, the base case maintains the potential to dispose of the CsSr glass as LLW after decay, which could offset the small volume difference with the glass option.

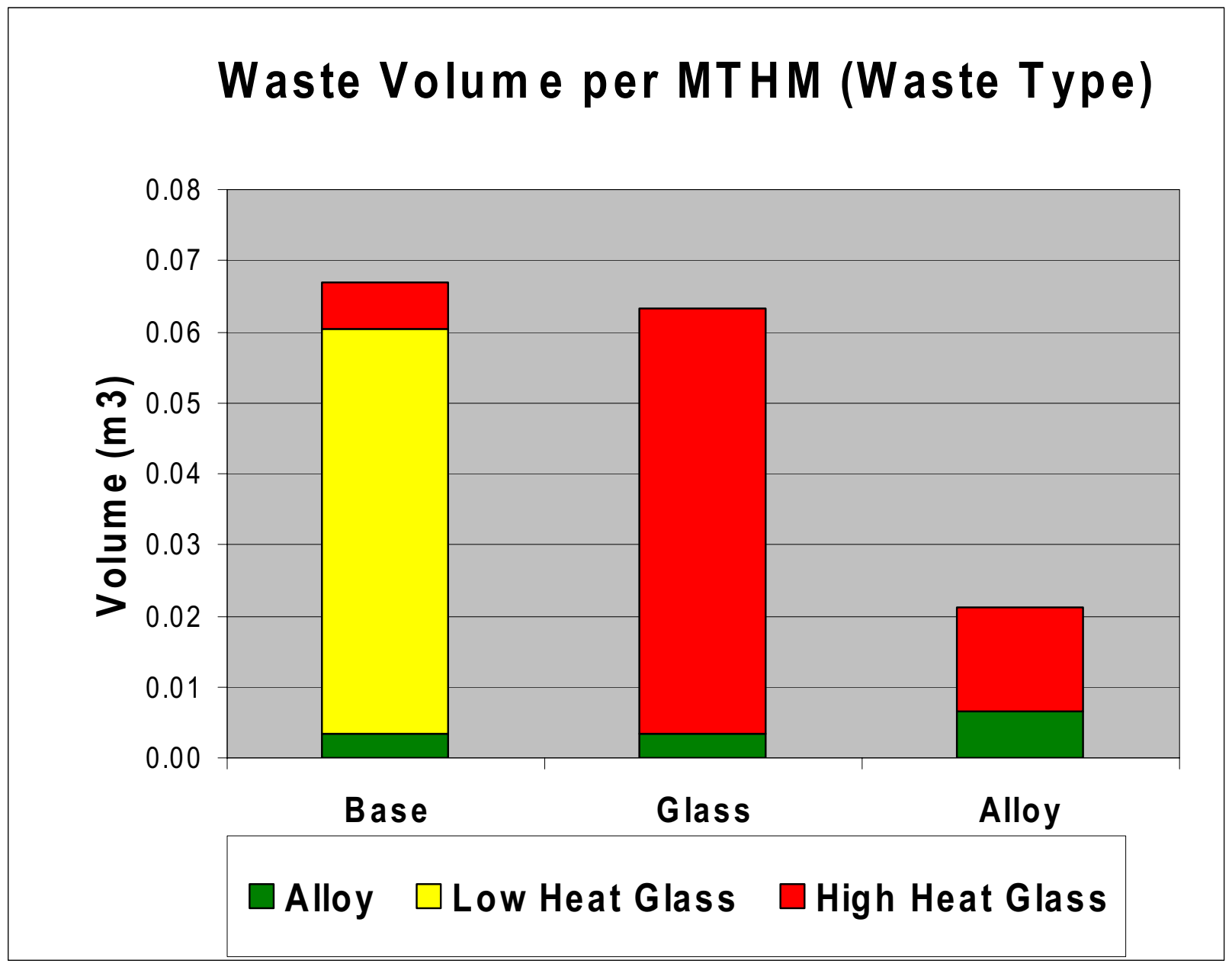

Figure 8. Comparison of waste management options by volume of waste.

In Figure 9 one can see the effects of weight and heat constraints. Figure 9 shows the number of canisters generated under the mass and heat constraints when reprocessing $800 \mathrm{MTHM} / \mathrm{yr}$. Starting with the baseline, one can see a dramatic shift from Figure 8; even though the high-heat glass is only $10 \%$ of the total volume in Figure 8, because of the high heat generation rate, it must be packaged in many more much smaller canisters, accounting for $\sim 60 \%$ of the total canister count. The glass option is now much more advantageous vs. the baseline than in Figure 8. Even though the high-heat glass is increased dramatically in volume $(\sim 9 \mathrm{x})$ due to the low solubility of the noble metals in the TMFP waste, the container size can now be nearly $3 \mathrm{x}$ larger in diameter ( $9 \mathrm{x}$ volume) because the specific heat generation 
$\mathrm{W} / \mathrm{m}^{3}$ is lower. Table 5 shows the data for this comparison, and the two factors of $9 \mathrm{x}$ cancel such that the heat generation for the canisters are essentially equal, even though the canister radii are a factor of $3 \mathrm{x}$ different. On the contrary, the alloy option is now much less advantageous. The count of alloy containers has only increased about $2 \mathrm{x}$ over the glass option, but the high-heat glass accounts for the majority of the containers and dominates the comparison. This is because the waste loading is higher in the high-heat glass for the alloy case, containing only $\mathrm{CsSr} / \mathrm{Ln}$ without the TMFP, and specific heat generation is intermediate between the baseline and glass options. As shown in Table 5, container size is still limited by decay heat: less than the baseline, but much more than the glass option. The intermediate size canister causes this option to have nearly as many total canisters $(86 \%)$ as the glass option. Table 6 summarizes the net affect of waste volume, mass, and decay heat in terms of canister count and potential savings for the waste form combinations under consideration. Though costs are allocated here as $\$$ package, it is also worth noting that the SNF standard package is $5.85 \mathrm{~m}$ long, whereas the long HLW package is only 5.30 $\mathrm{m}$ long. So for every HLW package used instead of a SNF package $\sim 0.55 \mathrm{~m}$ of drift can be saved. A more detailed study with all repository design costs available might therefore place a slightly reduced cost on placing the HLW package because drift construction (but not handling) costs are $\sim 10 \%$ less. The comparison in Table 6 uses level \$/package costs, but does show the potential for lineal efficiency.

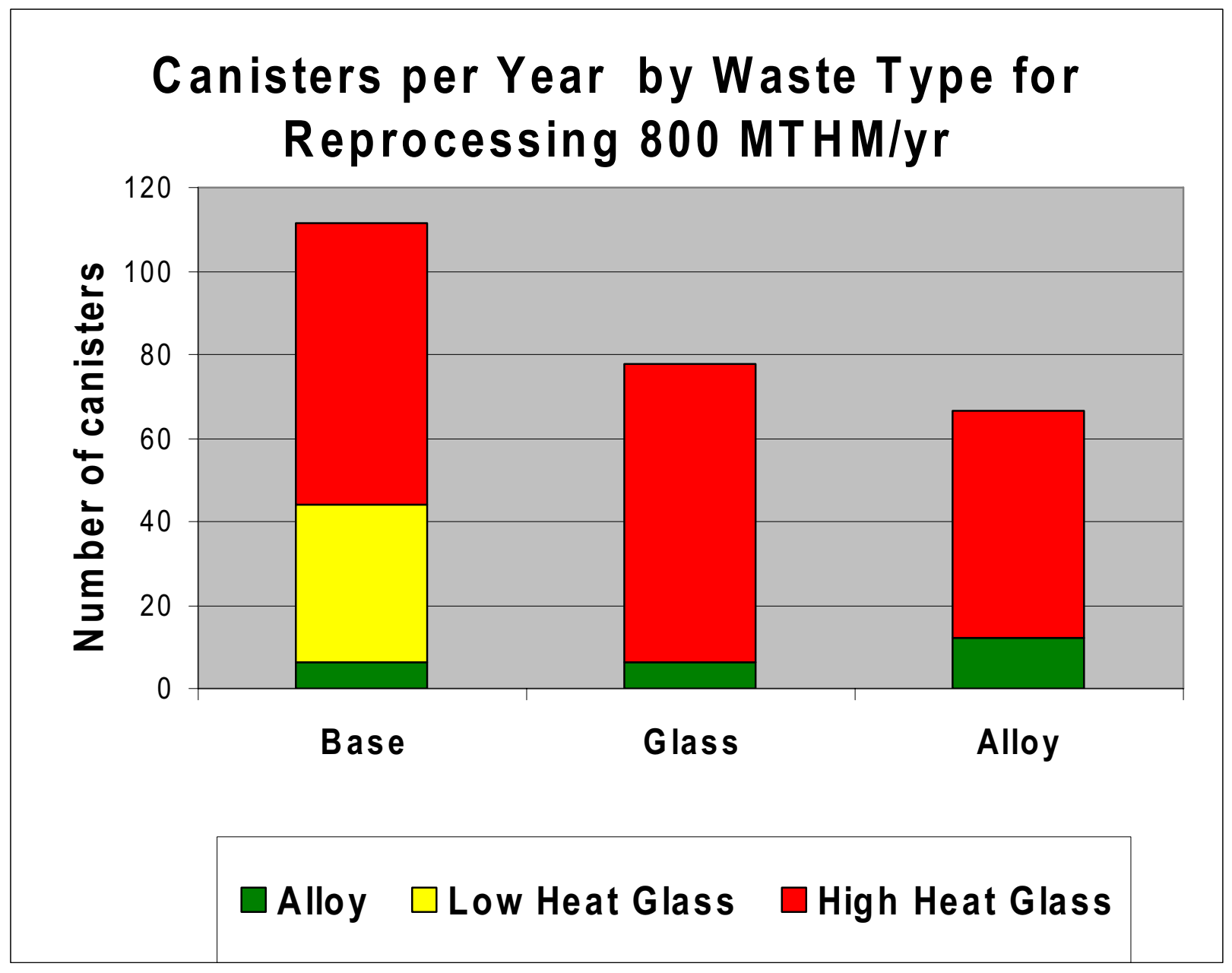

Figure 9. Comparison of waste management options by number of waste canisters.

As can be seen in Table 6 , the HLW management options with reprocessing could save up to $\sim \$ 400 \mathrm{M} / \mathrm{yr}$ in repository costs for an $800 \mathrm{MTHM} / \mathrm{yr}$ throughput. Coincidentally, this almost exactly offsets the costs 
once projected for separations; estimated to be $\sim \$ 500 / \mathrm{kg},{ }^{16}$ or $\$ 400 \mathrm{M}$ for $800 \mathrm{MTHM} / \mathrm{yr}$. Of course, to implement any waste management strategy there are also all of the waste processing costs to consider. The goal of this trade-study is to evaluate the relative cost benefit among the HLW management strategies following reprocessing. The Table 6 results also show the dollar savings of either the glass or alloy options relative to the three-waste-form base case is $\sim \$ 30-40 \mathrm{M}$. This sets the bar for the initial differences amongst the strategies; for one strategy to be markedly advantageous to another it will have to be significantly less expensive to implement and operate reliably, or must provide some other compelling intangible benefit of greater value than the purely economic differences.

One last observation is that the HLW management strategies also reduce the repository drift length used by up to a factor of ten over direct disposal of SNF. This is ultimately the real differential versus direct disposal of SNF rather than comparison of HLW volume or mass. These waste strategies based on advanced aqueous separations, using combined waste forms and storage to allow radioactive decay and heat dissipation, make it possible to place up to 10x the HLW equivalent of SNF in the same repository space. Conversely, this also means that to accomplish the goal of putting greater than a factor of 10x more SNF equivalent as HLW in the repository, additional measures must be taken. One option would be to reprocess older fuel to reduce the waste decay heat such that larger containers could be used for the high waste loading glasses, thereby reducing the number of containers. Other possibilities include designing a waste container to dissipate heat more effectively, increasing the allowable filled canister weight limit, or developing waste forms that can tolerate greater temperatures. This is beyond the scope of this analysis, but a thermal management strategy could build on these results.

Table 6. Waste strategy SNF/HLW disposal comparison for $800 \mathrm{MTHM} / \mathrm{yr}$

\begin{tabular}{|l|c|c|c|c|}
\hline \multicolumn{1}{|c|}{ Waste/Parameter } & $\begin{array}{c}\text { SNFDirect } \\
\text { Disposal }\end{array}$ & Baseline & $\begin{array}{c}\text { Glass } \\
\text { Option }\end{array}$ & $\begin{array}{c}\text { Alloy } \\
\text { Option }\end{array}$ \\
\hline SNF & $\bullet$ & & & \\
\hline Ln/TMFP Glass & & $\bullet$ & & \\
\hline CsSr Glass & & $\bullet$ & & $\bullet$ \\
\hline CsSr/Ln Glass & & & & $\bullet$ \\
\hline CsSr/Ln/TMFP Glass & & $\bullet$ & $\bullet$ & \\
\hline UDS/TC Metal & & & & $\bullet$ \\
\hline UDS/TC/TMFP Metal & 1.97 & 0.067 & 0.063 & 0.021 \\
\hline Total Volume m ${ }^{3}$ MTHM & - & 0.140 & 0.097 & 0.083 \\
\hline Canisters/MTHM & - & 112 & 78 & 67 \\
\hline Canisters/yr 800 MTHM/yr facility & 89 & 19 & 13 & 11 \\
\hline Waste Packages yr & - & $79 \%$ & $85 \%$ & $88 \%$ \\
\hline Package Efficiency vs SNF & 521 & 99 & 69 & 59 \\
\hline Drift Length Used & - & $81 \%$ & $87 \%$ & $89 \%$ \\
\hline Lineal Drift Efficiency vs SNF & 454 & 95 & 66 & 57 \\
\hline HLW Disposal Cost \$M & - & 359 & 388 & 397 \\
\hline $\begin{array}{l}\text { Potential HLW Disposal Savings vs SNF } \\
\text { \$M/yr }\end{array}$ & - & $79 \%$ & $85 \%$ & $88 \%$ \\
\hline Potential HLW Disposal Savings vs SNF \% & - & - & 29 & 38 \\
\hline $\begin{array}{l}\text { Potential HLW Disposal Savings vs } \\
\text { Baseline \$M/yr }\end{array}$ & - & & & \\
\hline
\end{tabular}




\section{PROCESS AND OPERATING COSTS}

Estimates of process and operating costs based on conceptual designs are highly speculative at early stages of development. While several cost estimates have been made, ${ }^{16}$ as research continues the estimates continue to change. Referring back to Figure 5, one can readily see that the differences between the glass and alloy strategies are few, and additional cost data is probably not needed. The glass option differs from the baseline by adding one process and subtracting three, whereas the alloy option requires adding two processes as well as subtracting two. On closer examination, it is apparent that both options add high-heat glass production and delete both low-heat glass and the $\mathrm{CsSr}$ waste form production, so these cancel from the comparison between the glass and alloy options. What is left is the glass option does not require the FPEX separation while the alloy option requires the TMFP reduction process. These processes are totally different, FPEX is a separations module that is based on several years of laboratory development as opposed to the TMFP reduction concept that has had essentially no development, hence the issue with direct comparison of highly speculative costs. Using the data from Table 6 , the difference in cost savings favors the alloy option over the glass option by only $\sim \$ 10 \mathrm{M} / \mathrm{yr}$. Just the operating costs of the more complex alloy option requiring both FPEX separations and the TMFP reduction processes are likely to exceed this savings. In addition, experience dictates, that for this small difference, one would always choose the simpler system for greater reliability. Therefore, unless there are significant changes to the design constraints, the glass option would be the economic choice. Note that the alloy option also includes a melting process to include UDS/Tc/TMFP compared to the baseline and glass option that alloy only the UDS/Tc. The addition of TMFP is a substantial amount of material to add to the melting process and would also add to the cost of this option but it is assumed to be offset by processing much less glass (Figure 8).

Comparison to the baseline is somewhat more challenging, and the evaluation becomes more reliant on judgment. Both the glass and alloy options require production of a high-heat glass (with $\mathrm{Cs} / \mathrm{Sr}$ ) versus the baseline process which produces both a low-heat glass (without $\mathrm{Cs} / \mathrm{Sr}$ ) and a high-heat $\mathrm{Cs} / \mathrm{Sr}$ glass. At the high waste loadings projected, processing the glass with $\mathrm{Cs} / \mathrm{Sr}$ will be more challenging than the a glass without $\mathrm{Cs} / \mathrm{Sr}$. Greater radioactivity will require additional shielding and greater likelihood of failure of non-metallic parts and instrumentation. Greater heat may require cooling or additional engineering to prevent solutions from inadvertently over-heating. However, in both cases the glass melting processes are essentially the same to the HLW glass processes performed worldwide over the last 30 years and both must be conducted in a hot-cell environment, which represents most of the cost. Preliminary design studies suggest that the additional costs for processing the higher activity solutions might add $\sim 10-15 \%$ to this single process. This is likely within the accuracy of the conceptual estimates. Offsetting this additional cost, the glass option allows deleting both the $\mathrm{Cs} / \mathrm{Sr}$ dedicated waste form process and the FPEX separation module. The capital and operating expenses of these two processes are intuitively greater than just a $10-15 \%$ increase in a single, well-known process; again the glass option is more economically effective given the current assumptions and design constraints. Put simply the glass option is less costly to build, and less costly to operate than the base case.

The alloy option competitiveness is less obvious in comparison to the baseline strategy. As with the glass option the high-heat versus low-heat glass process costs are probably too close to differentiate significantly between the strategies. Also the FPEX separations module is still needed so this does not differentiate versus the baseline. Assuming that the increased melter throughput for the metal alloy is offset by the reduced glass throughput (Figure 8), this leaves the subtraction of the $\mathrm{Cs} / \mathrm{Sr}$ waste immobilization process to offset the additional cost of the TMFP reduction process. Neither of these processes have been done, and both are very conceptual. For purposes of this study, the $\mathrm{Cs} / \mathrm{Sr}$ waste form has been assumed to be vitrification to make a very high-heat glass. Thus the $\mathrm{Cs} / \mathrm{Sr}$ waste form process can be modeled as another glass plant with evaporation, materials handling and a melter. The TMFP process will require significantly more volume reduction by evaporation of the process solution from the 
TRUEX process. In addition, the metals must be chemically or electrochemically reduced to high efficiency, recovered as metals, and conveyed to the metal melter cell for combination with UDS/Tc. At that point the processes become similar to vitrification with materials handling and a melter, though the alloy process will be far lower activity than the $\mathrm{Cs} / \mathrm{Sr}$ process. This total process including evaporation and metal reduction/recovery with far greater liquid volume throughput will use $\sim 2 \mathrm{x}$ the hot-cell space as the $\mathrm{Cs} / \mathrm{Sr}$ waste reduction prior to melting and therefore requires at least a $50 \%$ premium in capital cost. This suggests that in rough order of cost/benefit, the glass option is better than the baseline, which is somewhat better than the alloy option. The alloy option is more expensive to build than the base case by the difference in cost between the $\mathrm{Cs} / \mathrm{Sr}$ immobilization and the TMFP reduction processes, estimated here at $\sim \$ 1 B$. As shown in Figure 10, it takes over 40 years for the alloy option cost profile to cross the base case.

These logical comparisons can be checked for reasonableness based on experience from preliminary design studies over the last decade of fuel reprocessing development. Capital costs are largely controlled by hot-cell space, with second-order impacts due to equipment. Thus similar processes can be compared if they have similar throughputs. Separations processes may use columns, centrifugal contactors, or mixer-settlers, but they all operate in hot-cells and use similar ancillary equipment. Waste vitrification processes all use melters in hot cells equipped to dissipate waste heat, relying on evaporators and material handling systems. Metal alloying processes are more developmental, using much smaller melters, but the support systems and cell design are similar to vitrification. The TMFP reduction system is so conceptual that it is estimated based on a waste immobilization system because it will still rely heavily on material handling and evaporation as described above, with the added cost of a chemical/electrochemical reduction process. While design concepts are in preliminary stages, rough estimates for these processes to support an $800 \mathrm{MTHM} / \mathrm{yr}$ reprocessing facility range from $\$ 300-500 \mathrm{M}$ per separation module and $\$ 2-5 \mathrm{~B}$ per waste immobilization process similar to glass melting. Annual operating costs are generally $1-3 \%$ of the capital cost for these facilities. Normalizing costs to the baseline as illustrated in Figure 5, and using the minimum values for these costs results in a comparison summarized in Table 7. This data is too generic to account for $10-15 \%$ differences like that described above between high and low-heat waste vitrification, but this is addressed in the following discussion on sensitivity. The TMFP reduction process will almost certainly cost more than the $\mathrm{Cs} / \mathrm{Sr}$ immobilization process, and is assumed here to cost $50 \%$ more. Figure 10 shows the projected cost comparison of the options setting the baseline costs to zero. Capital costs differences define the y-axis intercepts with the HLW disposal savings combined with process operating costs defining slopes. The periodic irregularities in the curves are the added costs of decay storage modules as they are built and add to operating costs. Also, HLW disposal cost savings do not start for fifteen years because the reprocessing plant has fifteen year surge storage capacity. The glass option has the lowest capital cost and trends lower because the annual operating costs are less than the base case. The alloy option starts higher because of the added capital cost for TMFP reduction, but eventually crosses the base case due to savings in HLW disposal. The degree of separation of the base case and alloy option are very sensitive to the concept costs for the TMFP reduction, but this projection shows the alloy option would not be competitive with the base case for over 40 years. 
Table 7. Capital and operating cost comparison for waste management strategies for $800 \mathrm{MTHM} / \mathrm{yr}$

\begin{tabular}{|c|c|c|c|c|}
\hline \multirow[b]{2}{*}{ Process } & \multicolumn{2}{|c|}{ Glass Option } & \multicolumn{2}{|c|}{ Alloy Option } \\
\hline & Capital (\$M) & Operating (\$M) & Capital (\$M) & $\begin{array}{c}\text { Operating } \\
(\$ M)\end{array}$ \\
\hline FPEX Separation & -400 & -4 & & \\
\hline Ln/TMFP Glass ${ }^{*}$ & -2000 & -20 & -2000 & -20 \\
\hline CsSr Glass $^{* *}$ & -2000 & -20 & -2000 & -20 \\
\hline CsSr/Ln Glass ${ }^{* *}$ & & & 2000 & 20 \\
\hline CsSr/Ln/TMFP Glass ${ }^{* *}$ & 2000 & 20 & & \\
\hline TMFP Reduction & & & 3000 & 30 \\
\hline Relative HLW Disposal $^{* * *}$ & & -29 & & -38 \\
\hline Difference vs. Baseline ${ }^{* * * *}$ & -2300 & -52 & 1000 & -28 \\
\hline \multicolumn{5}{|c|}{$\begin{array}{l}{ }^{*} \text { Used in baseline concept only, subtracted from both options } \\
{ }^{* *} \text { Using generic data all of the vitrification processes have similar costs, though follow-on studies may more closely evaluate } \\
\text { cost vs. throughput } \\
\text { ***** HLW disposal cost savings at the repository is essentially an annual operating cost to reprocessing, even though it includes } \\
\text { capital costs } \\
\text { ******al Metal melting processes following the chemical reduction of wastes are considered substantially offset by reduced glass } \\
\text { production, though follow-on studies may more closely evaluate cost vs. throughput }\end{array}$} \\
\hline
\end{tabular}

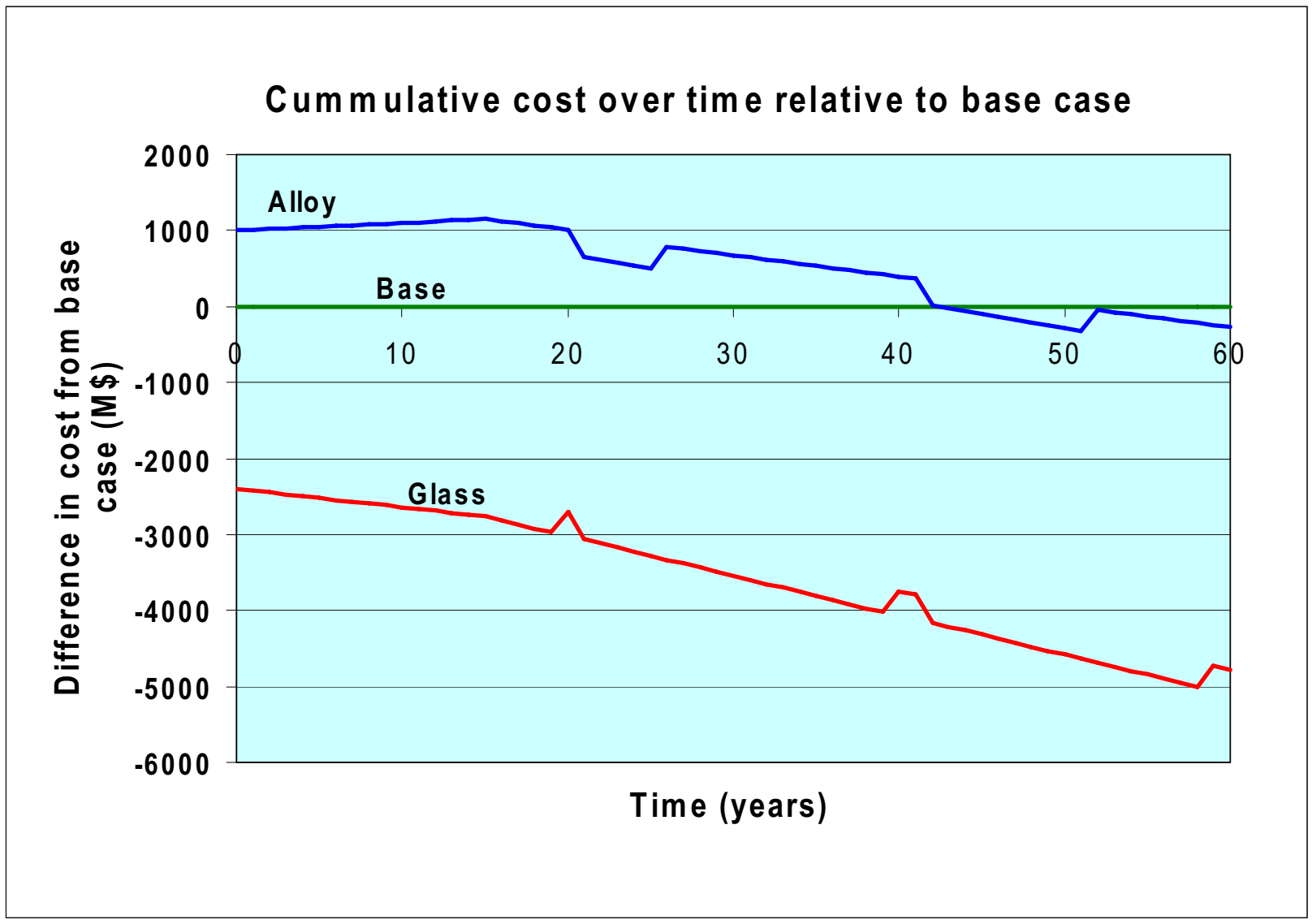

Figure 10. Comparison of waste strategy costs over time normalized to baseline 


\subsection{Sensitivity Studies}

\subsubsection{Disposal as LLW vs HLW}

Separation of $\mathrm{Cs} / \mathrm{Sr}$ and use of a dedicated waste form for these elements could facilitate disposal as LLW after sufficient decay. ${ }^{17}$ Even if combined with the Ln waste, after decay the material could possibly be considered LLW if the radionuclide lists in 10CFR 61, which define the range of concentrations allowable in LLW are expanded. ${ }^{17}$ LLW disposal costs are much lower than those for HLW. Disposing of the Cs/Sr and the $\mathrm{Cs} / \mathrm{Sr} / \mathrm{Ln}$ glasses as LLW would reduce the waste disposal costs for the base case by $\sim 60 \%$ and $\sim 85 \%$ for the alloy case. The effect on the overall cost profile is significant, but does not change the overall ranking as shown in Figure 11.

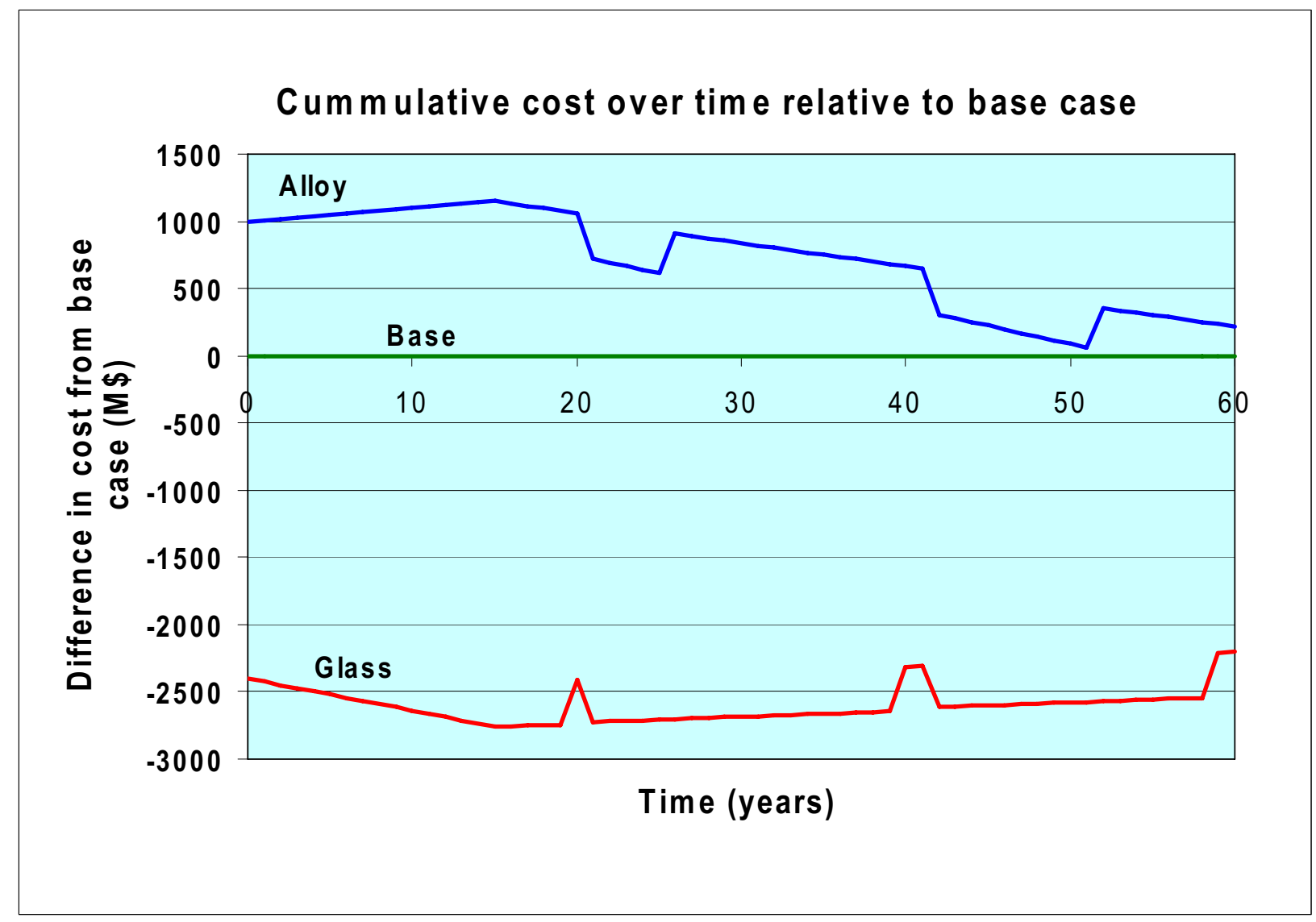

Figure 11. Comparison of waste strategy costs over time normalized to baseline with $\mathrm{Cs} / \mathrm{Sr}$ and Ln waste disposed as LLW.

\subsubsection{Weight Limit}

The weight limit constrains only the potential benefit of the alloy option. A weight limit severely restricts the amount of metal that can be put into a waste canister, thereby increasing disposal costs. This can be tested in the spreadsheet by defaulting to an unrestricted loading and allowing full-sized canisters to be filled with this low-heat waste. This decreases the annual canister production to 108,73 , and 50 , or a net decrease of 4, 5, an 8 canisters per year for the base, glass, and alloy options respectively. This translates to HLW disposal cost savings of about $\$ 3,5$, and $6 \mathrm{M}$, which is about $\sim 10 \%$ of the relative benefit versus direct disposal of fuel, but it does not significantly impact the relative ranking of the options. 


\subsubsection{Separations Additives}

The primary reagent added in the separations process carried over into the waste is ferrous-sulfamate. Sulfur is problematic in most stabilization processes and must be removed before or during any melter operation. This must be factored into the process design and costing the designs accurately will require additional development beyond the scope of this study. The iron could impact the amount of either the glass or the alloy. The costs of any process for the TRUEX waste containing TMFP and the iron could be affected. This can also be evaluated to some degree in the spreadsheet. The $\mathrm{CsSr} / \mathrm{Ln} / \mathrm{TMFP}$ glass at $\sim 45 \%$ waste loading contains three weight percent oxides of the noble metal $\mathrm{Ru}, \mathrm{Rh}, \mathrm{Pd}$. The limited solubility of these metals sets the basis for the overall waste loading of this stream. Beyond this loading, process upsets are likely in a joule-heated melter based on passing electrical current through the molten glass. Even though the iron oxide makes up almost half (about $46 \mathrm{wt} \%$ ) of the waste oxide fraction of the glass, and about $21 \mathrm{wt} \%$ of the glass waste form, elimination of the iron would just mean more glass additives added to make roughly the same amount of glass because the noble metals would still limit the waste loading. The same would be true of the Ln/TMFP glass in the base case; the iron has no impact.

The combined UDS/Tc/TMFP alloy is based on a roughly $15 / 85$ ratio of $\mathrm{Zr} / \mathrm{Fe}$ to make a relatively low melting point alloy. Much of the required iron comes from the TRUEX ferrous sulfamate, but additional iron would still be added as either non-radioactive process chemical or from activated hardware recovered during SNF shearing in the reprocessing plant. If the ferrous sulfamate was deleted, iron is still needed to make the alloy. It is possible that additional activated hardware could be disposed in this manner, thereby reducing the low level waste stream, but the overall HLW mass and volume would not be reduced.

Therefore, even though the added iron is a significant mass, it does not appear that it has a significant effect on any waste management strategy. If possible, the use of ferrous sulfamate should still be avoided to eliminate the significant melting process difficulties caused by sulfur.

\subsubsection{Fuel Age and Heat Limit}

The basis SNF for this analysis is 20 year cooled, $51 \mathrm{GWd}$ /MTHM. Decay heat from all waste streams is calculated based on Origen data for that fuel profile. All of the $\mathrm{Cs} / \mathrm{Sr}$ bearing glasses generate too much heat to allow the use of full sized $0.61 \mathrm{~m}$ diameter waste canisters without exceeding the centerline temperature at which the glasses become unstable and devitrify. Similar to the weight limit, this makes it necessary to produce more canisters, which reduces the HLW disposal savings. One option is to process older fuel. The wastes would be decayed further, allowing the use of larger containers. Glass quantity is based on chemistry, so this would be unchanged unless the daughter products from the decay of the fission products are significantly less soluble than the original fission products. Assuming constant solubility, the spreadsheet can be used to test the concept of aging the fuel. Aging the fuel 30 additional years ( 50 total) reduces the specific heat generation by a factor of two, 30 more a factor of 4 , and 30 more a factor of 8 .

As the age of fuel processed is increased the first 20 years (total of 40), the glass option is no longer heat limited, but the effects on canister count is similar for both the glass and alloy options at $\sim 40 \%$ fewer canisters. The $\mathrm{Cs} / \mathrm{Sr} / \mathrm{Ln}$ glass in the alloy case is heat limited until the fuel is a total of 79 years old, and the $\mathrm{Cs} / \mathrm{Sr}$ glass in the base case until the fuel is 112 years old. As the fuel gets older, the relative advantages in HLW disposal costs for the glass and alloy options over the base case are reduced. Eventually, the HLW disposal costs for the glass and base cases are essentially equal with a residual benefit of the alloy case of $\sim \$ 24 \mathrm{M} /$ year. Figure 12 shows the relative cost profiles after 112 years. This is equivalent to having no heat limit or a waste form that is insensitive to heat. Comparing Figures 10 and 12 it is apparent that the glass option remains the most cost-effective, though the magnitude of the total savings is diminished. The alloy option actually becomes less competitive over time because of the relative difference in total operating costs. 


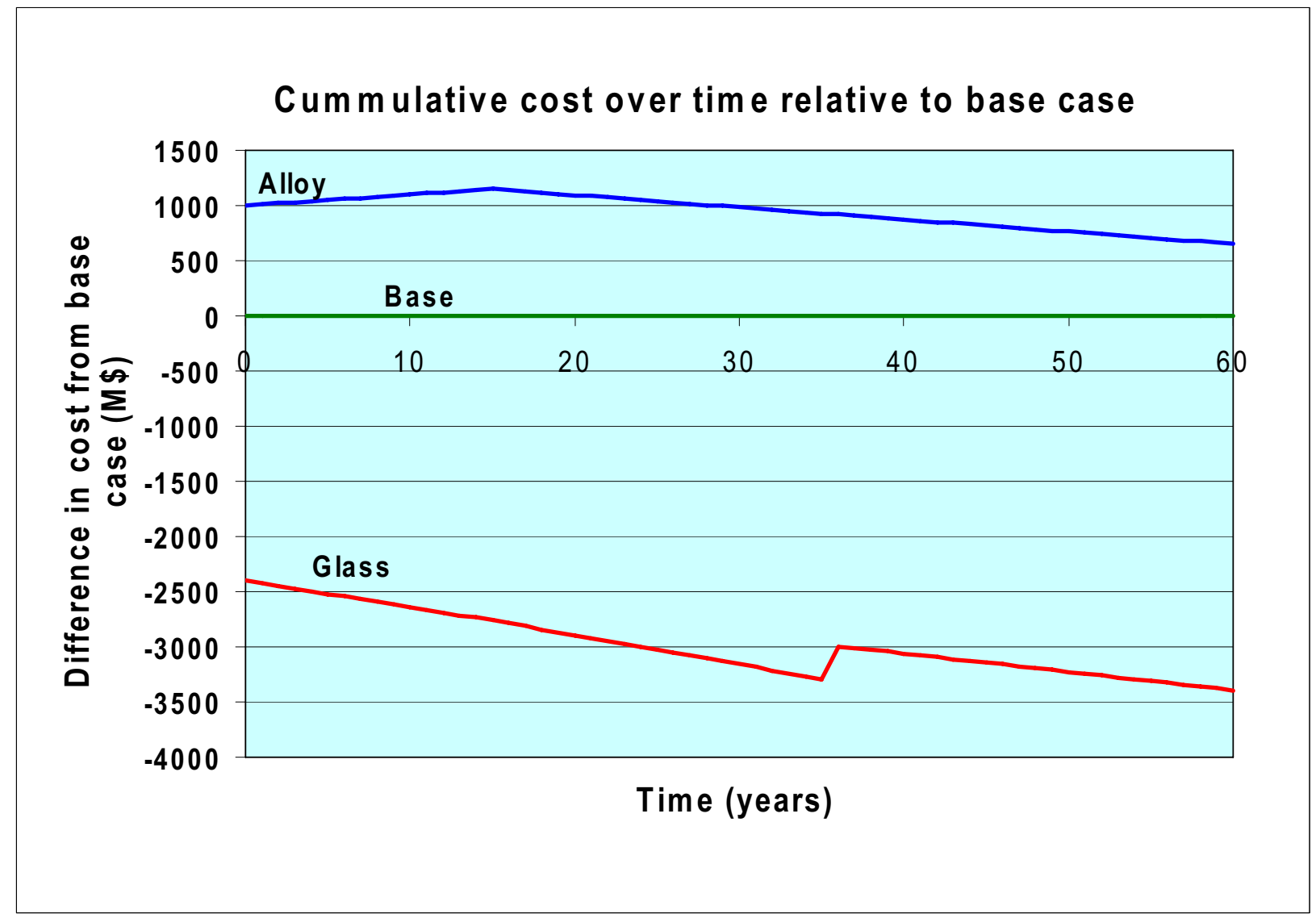

Figure 12. Comparison of waste strategy costs over time normalized to baseline with fuel aged $\sim 112$ years total or eliminating the heat limit.

\subsubsection{Waste Loading}

The waste loadings used in this analysis are at the high end of the estimated ranges. This was intentionally chosen to determine which strategy would be most cost-effective if waste form development was highly successful. Sensitivity testing reducing the glass waste loadings by a factor $2 \mathrm{x}$ changes the profiles, but not the overall rankings of the strategies for $\sim 30$ years of operation as shown in Figure 13.

\subsubsection{Canister Disposal Cost}

A nominal canister disposal cost of $\$ 850 \mathrm{~K}$ was selected for this analysis. However, as described above, this value could readily be estimated perhaps $\pm 20 \%$. Using the spreadsheet the HLW canister disposal cost was varied from $\$ 700 \mathrm{~K}-\$ 1 \mathrm{M} /$ canister. Naturally, total disposal costs and relative annual savings were affected linearly. The overall changes in profile for the base case and options were negligible. 


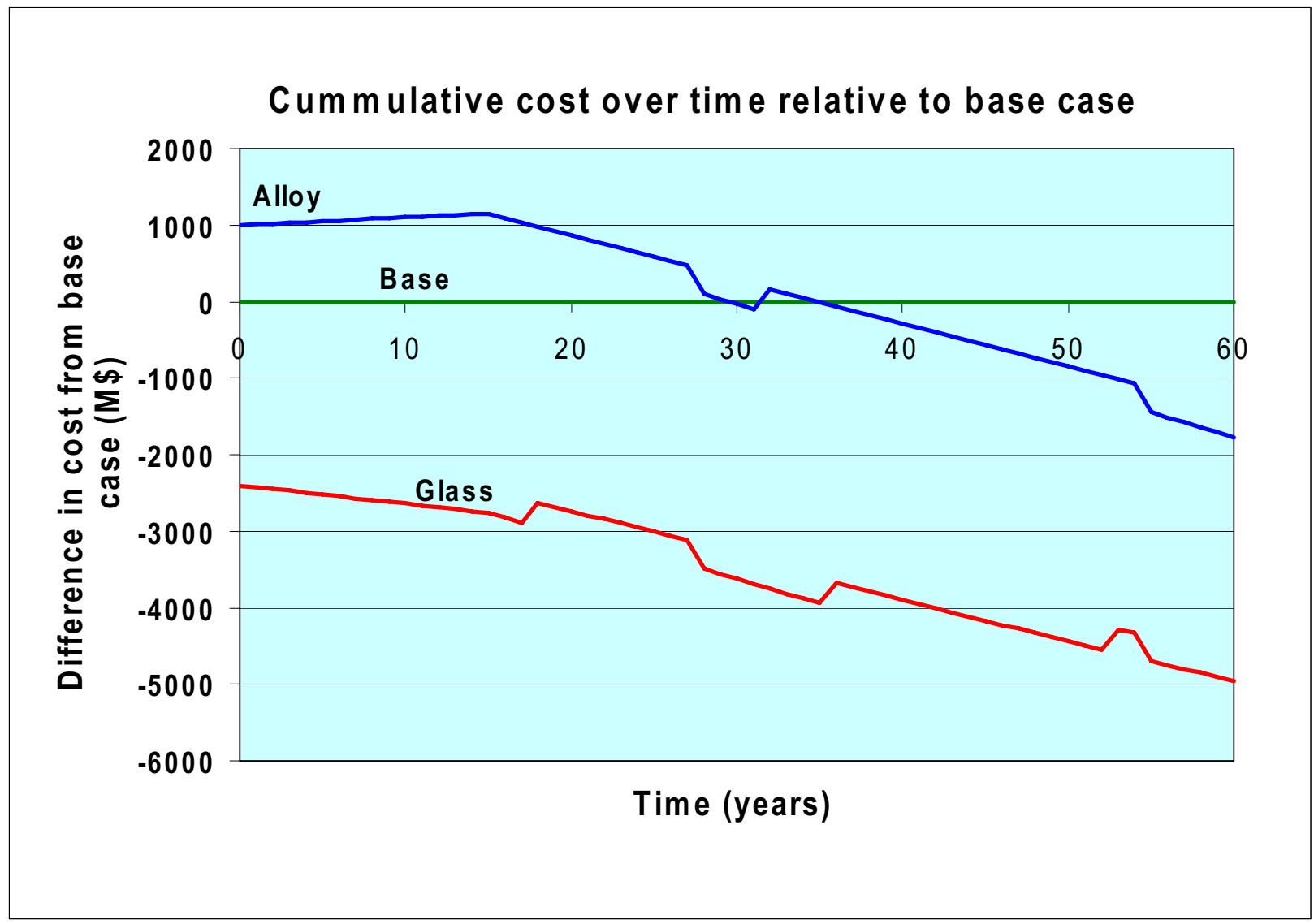

Figure 13. Comparison of waste strategy costs over time normalized to baseline with glass waste loading reduced $50 \%$.

\subsection{Option 3 All Glass}

The results to this point indicate that it is difficult to offset capital costs for additional waste form processes that reduce HLW volume with the savings in disposal costs. The logical extension of this is a strategy in which all of the non-actinide wastes are combined in one waste form. Alkali/alkaline-earth elements are not stable in a reduced metallic form, so if one waste form is to be used it is likely to be glass even if it includes some small inclusions of the noble metals as metallic droplets. As stated above, the waste loading is limited to about $3 \mathrm{wt} \%$ of the noble metal oxides. This HLW waste process is very similar to what is used today, but the waste management strategy differs significantly in 1) recycling the actinides for energy recovery and transmutation, and 2) decay storage to manage heat from the HLW glass prior to final disposition. These key differences enable more efficient use of a repository.

Recalculating the data in Table 6 for a glass that contains all wastes (UDS/Tc/CsSr/Ln/TMFP), limited to $3 \mathrm{wt} \%$ noble metal oxides, results in a waste loading of $32.7 \%$, with a production of $\sim 0.1$ $\mathrm{m}^{3} /$ MTHM. Comparing to the volume data in Table 6 shows that this is $\sim 50 \%$ greater than either the base case or the glass option and over 4.6x the alloy option. However, with a density of $\sim 2.7 \mathrm{MT} / \mathrm{m}^{3}$ the waste canister in not weight limited, and because of the relatively low waste loading it is not heat limited. Thus, the resulting larger glass volume can be packaged in larger full-sized $0.61 \mathrm{~m}$ diameter canisters, and the packaging efficiency calculations result in repository efficiency data essentially the same as for the lowest volume alloy option. 
The all-glass option has capital costs similar to the glass option as shown in Figure 5, with the exception of also eliminating the cost of technetium reduction and alloying with the UDS. The technetium processing can likely be accomplished in a glove box, which is much less costly than a hot-cell. Melting with the UDS may require additional shielding, but for the purposes of this comparison, it is assumed that the Tc/UDS waste processing is negligible. Operating costs for decay storage are essentially equal to the to the decay storage costs for the base case, because the canister numbers are coincidentally very similar. One significant difference is in HLW disposal. The all-glass option produces only one waste form, and it contains $\mathrm{Cs} / \mathrm{Sr}$, so all of the canisters stay in decay storage for $\sim 100$ years. This means that there are no HLW disposal costs for 100 years, and repository operations are postponed 100 years. This results in the long-term cost profiles shown in Figure 14. Note that Figure 14 is for illustration only and does not reflect the additional capital costs of new facilities over the extended time frame. As in the other profiles, the base case overlies the time-axis and is not visible in the figure.

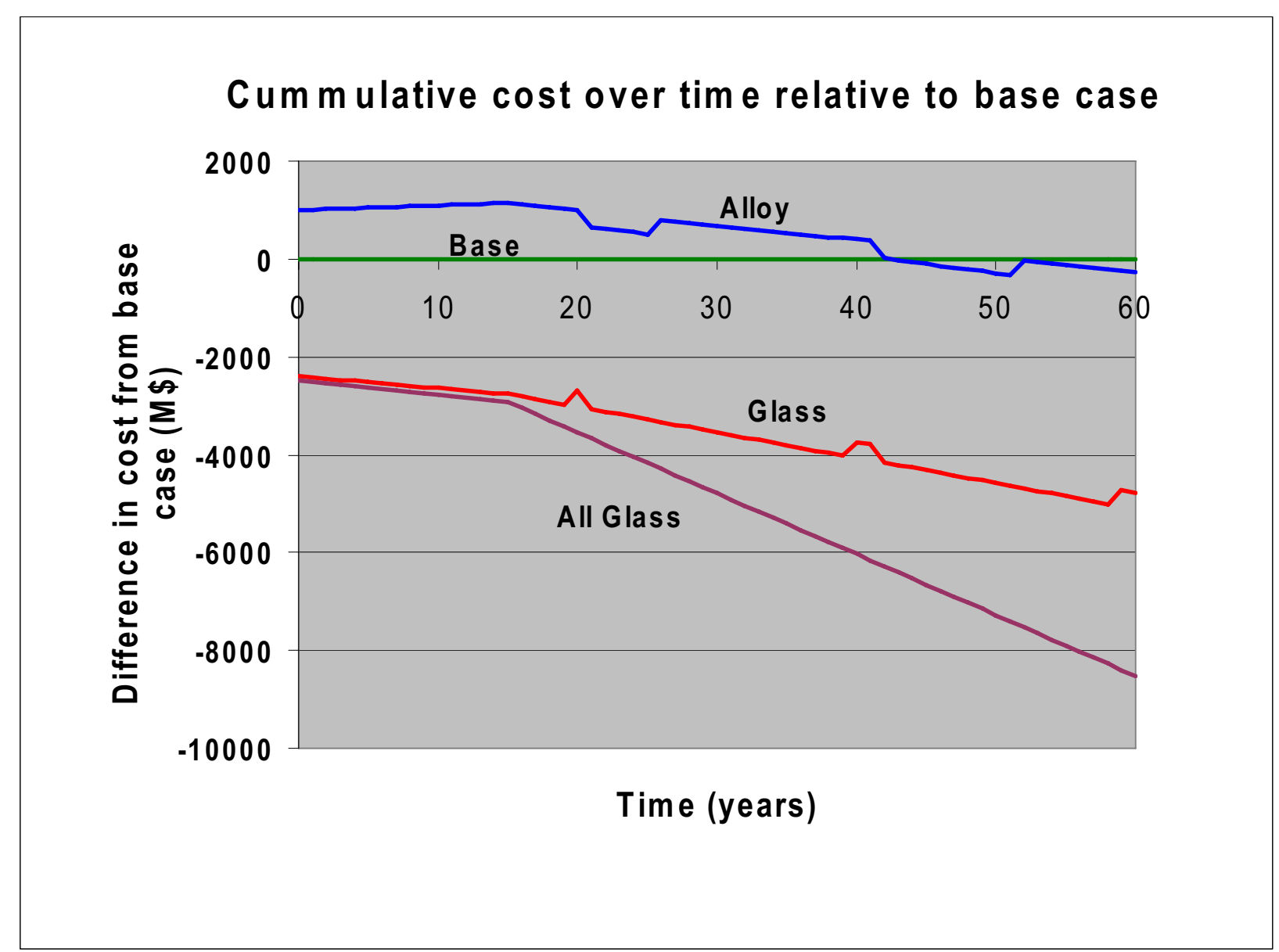

Figure 14. Long-term cost profile of one glass waste form versus other waste management strategies.

Comparing the two lower curves, the solid line representing the all-glass option overlays the glass option only as long as the surge storage of HLW lasts (in this case set to 15 years). As soon as repository operations begin and HLW disposal costs are accounted for, the all-glass option becomes increasingly competitive because there is no disposal for this option until decay storage is over at 100 years. At the end of a century of operations, the decay storage interval is over for the first waste generated, and annual shipment to the repository equal the annual production rate. There is then is a slight inflection point in the all-glass curve, but it continues to increase the cost differential because it generates fewer canisters than the glass option (as few canisters as the alloy option) and has much lower operating expenses. 
The all-glass option is made even more cost-effective if any credit is allowed for not processing the Tc/UDS alloy. Relative costs of the all glass option are not sensitive to the weight limit. Depending on the facility capital and operating costs used, fuel age can make the all-glass option somewhat less competitive with the glass option after 100 years when all options incur HLW disposal costs, but generally, unless the fuel is aged for several more decades and capital costs are significantly changed, the all glass option stays the most cost-effective.

\section{CONCLUSIONS}

Advanced separations allow development of waste management strategies that were not conceivable with simple PUREX reprocessing. For the first time matching the waste form to the waste is possible for HLW; metals can be segregated from oxides and each can be separated and stabilized in forms to minimize the volume of HLW for disposal in the repository. Combining all of the metals UDS/Tc/TMFP in a metallic form and the oxides of $\mathrm{Cs} / \mathrm{Sr} / \mathrm{Ln}$ in glass results in a minimum HLW volume, but due to process capital and operating costs, this is not the most cost-effective solution. Using generic costs for typical waste stabilization facilities and separations modules based on preliminary conceptual studies, it appears that the current international standard of stabilizing all wastes together in one HLW glass is the most cost-effective waste management strategy. However, it is essential to reducing the long-term heat in a repository to note that separation of the actinides is the most important distinction between the all-glass option in this study and the current international standard.

Sensitivity studies considering weight and heat, separations additives, waste loading and HLW canister disposal costs indicate that this conclusion is robust over a wide range of these variables. This is due to the fact that relative HLW disposal savings amongst the four strategies are measured in multiples of $\$ 10 \mathrm{M}$ similar to facility operating costs, whereas the capital costs are in multiples of $\$ 1 \mathrm{~B}$. Thus it is very difficult to justify the costs of dedicated HLW treatment facilities purely on reducing HLW disposal costs based on canister count. Setting a greater premium on incremental repository space savings may be warranted by placing a value beyond capital and operating costs on delaying the need for an additional repository. There are other reasons to consider different waste forms including durability and interactions with the repository.

A HLW management strategy enabled by advanced aqueous separations, using state-of-the-art combined waste forms and storage to allow radioactive decay and heat dissipation, makes it possible to place up to 10x the HLW equivalent of SNF in the same repository space. Conversely, this also means that to accomplish the goal of putting greater than a factor of 10x more SNF equivalent as HLW in the repository, additional measures must be taken, such as redesign to provide more physical space. As shown above this lowest volume option is not likely the most cost-effective. Far more important than reducing volume is 1) recycling the actinides for energy recovery and transmutation, and 2) decay storage to manage heat from the HLW glass prior to final disposition. This strategy makes the repository temperature constraints non-limiting, and then canister disposal costs are primarily a function of transportation, handling, and drift length in the repository. An added benefit is reduction of long-term radiotoxicity of the waste by removing the actinides. Once these steps are taken, it appears that alternate strategies can be evaluated based on the number of canisters they produce.

\section{RECOMMENDATIONS}

The results from this study should be leveraged for use in a follow-on trade-study for an overall HLW management strategy considering heat. The ultimate constraint on a repository is long-term performance to limit potential dose to the public, but within that design criterion strategic management of decay heat can maximize the amount of material that can be safely disposed. Further, the performance of a repository 
containing primarily high-integrity waste forms and a small amount of unprocessable SNF can be expected to be markedly different than the current design containing primarily SNF, requiring additional assessment of the expected material degradation rates and how they impact expected dose. These results may allow reconsideration of engineered barriers affecting overall costs.

Waste form R\&D priorities should be revaluated as well. To the extent the assumptions in this study are valid it appears the results are robust for all of the variables considered. Key limiting parameters are the glass transition temperature, which controls container size and drives costs, and noble metal solubility which limits waste loading and drives glass volume. A glass/ceramic waste form that is not as sensitive to heat and/or stabilizes a greater concentration of noble metals would allow greater waste loading and fewer canisters. The benefits are reduced HLW disposal cost and perhaps more importantly less risk due to transportation. This new waste form should not require powder handling, and optimally have a density at least as high as glass $\left(2.7 \mathrm{MT} / \mathrm{m}^{3}\right)$ and a leach rate on a mass basis that is at least as good as glass. A specific radionuclide of interest is ${ }^{99} \mathrm{Tc}$. A ceramic form created using a melting process could be a useful option. Such a waste form would benefit the glass option as well as the all-glass option. The alloy option does not warrant further development at this time.

Beyond the primary separations process wastes, capture and stabilization of volatile radionuclides will be a significant challenge. High-efficiency separation of iodine, $\mathrm{Kr}, \mathrm{CO}_{2}$ (containing ${ }^{14} \mathrm{C}$ ), and ${ }^{3} \mathrm{H}$ are essential to reducing secondary wastes and meeting current regulations. It is very desirable to isolate both iodine and ${ }^{3} \mathrm{H}$ early in the reprocessing flowsheet to minimize waste treatment costs.

Lastly, waste metals including both cladding and activated stainless steel should be evaluated for potential recycle, both to avoid waste management of likely greater than Class C (GTCC) wastes, and to maximize reuse of nuclear-grade Zircaloy. A combined metal waste form is very attractive to stabilize technetium, and may still prove useful if a cost competitive process can be found to reduce the metals and form the alloy.

\section{REFERENCES}

1. Pereira, C., et al "Lab-Scale Demonstration Of The UREX+1a Process Using Spent Fuel," WM'07 Symposium, February 25, - March 1, 2007, Tucson, AZ

2. Law, J. D., et al, "Development of Cesium and Strontium Separation and Immobilization Technologies in Support of an Advanced Nuclear Fuel Cycle," WM'06 Symposium, February 26 March 2, 2006, Tucson, AZ

3. Gombert II, D., et al, "Global Nuclear Energy Partnership Integrated Waste Management Strategy Waste Treatment Baseline Study," GNEP-WAST-WAST-AI-RT-2007-000324, September 2007.

4. Gombert II, D. et al, "Global Nuclear Energy Partnership Integrated Waste Management Strategy," GNEP-WAST-WAST-AI-RT-2008-000214, Rev. 1, May 2008

5. The Act consists of the Act of Jan. 7, 1983 (Public Law 97-425; 96 Stat. 2201), as amended by P.L. 100-203, Title V, Subtitle A (December 22, 1987), P.L. 100-507 (October 18, 1988), and P.L. 102-486 (The Energy Policy Act of 1992, October 24, 1992). The Act is generally codified at 42 U.S.C. 10101 and following.

6. Gombert II, D., Roach, J. A. et al "Global Nuclear Energy Partnership Integrated Waste Management Strategy Technical and Policy Issues for Implementation,” INL/EXT-07-12620, Revision 0, May 2007.

7. "The Analysis of the Total System Life Cycle Cost (TSLCC) of the Civilian Radioactive Waste Management Program,” DOE/RW-0591, July 2008 
8. Yucca Mountain Science and Engineering Report, Rev. 1, U.S. DOE, Office of Civilian Radioactive Waste Management, DOE/RW-0539-1, February 2002.

9. "Preliminary Transportation, Aging and Disposal Canister System Performance Specification Revision B," Office of Civilian Radioactive Waste Management, WMO-TADCS-000001, $D O E / R W-0585$, November 2006

10. "Yucca Mountain Repository License Application: Safety Analysis Report," Office of Civilian Radioactive Waste Management, DOE/RW-0573, Rev. 0, June 2008

11. Bodansky 2004, Bodansky, D., Nuclear Energy, Springer-Verlag, New York, 2004, 693 pp.

12. "Waste Acceptance System Requirements Documents" DOE/RW-0351 rev 5, DOC.20070522.0007, May 31, 2007

13. Wigeland, R. A. and Bauer, T. H., "Repository Benefits of AFCI Options," Argonne National Laboratory, ANL-AFCI-129, September 3, 2004.

14. Stillman, J. A. et al. "Follow-Up Analyses for the ANTT Review," Argonne National Laboratory, ANL-AFCI-132, September 30, 2004.

15. Rohsenow, W. M., Hartnett, J. P., Handbook of Heat Transfer, McGraw Hill, 1973, p. 3-109

16. Shropshire, D. E. et al, “Advanced Fuel Cycle Cost Basis,” INL/EXT-07-12107, March 2008

17. Gombert II, D. et al, "Global Nuclear Energy Partnership Integrated Waste Management Strategy,” GNEP-WAST-WAST-AI-RT-2008-000214, Rev. 1, May 2008 